\title{
Mechanisms of cell uptake, inflammatory potential and protein corona effects with gold nanoparticles
}

\begin{abstract}
Aim: To assess inflammation, cellular uptake and endocytic mechanisms of gold nanoparticles (AuNP) in human epidermal keratinocytes with and without a protein corona. Materials \& methods: Human epidermal keratinocytes were exposed to 40 and $80 \mathrm{~nm}$ AuNP with lipoic acid, polyethylene glycol (PEG) and branched polyethyleneimine (BPEI) coatings with and without a protein corona up to $48 \mathrm{~h}$. Inhibitors were selected to characterize endocytosis. Results \& conclusion: BPEI-AuNP showed the greatest uptake, while PEG-AuNP had the least. Protein coronas decreased uptake and affected their mechanism. AuNP uptake was energy-dependent, except for $40 \mathrm{~nm}$ lipoic-AuNP. Most AuNP were internalized by clathrin and lipid raft-mediated endocytosis, except for $40 \mathrm{~nm}$ PEG was by raft/noncaveolae mediated endocytosis. Coronas inhibited caveolae-mediated-endocytosis with lipoic acid and BPEI-AuNP and altered $40 \mathrm{~nm}$ PEG-AuNP from raft/noncaveolae to clathrin. Inflammatory responses decreased with a plasma corona. Results suggest protein coronas significantly affect cellular uptake and inflammatory responses of AuNP.
\end{abstract}

First draft submitted: 11 August 2016; Accepted for publication: 30 September 2016; Published online: 10 November 2016

Keywords: endocytosis $\bullet$ gold nanoparticles $\bullet$ human epidermal keratinocytes

- inflammation • mechanisms of cellular uptake $\bullet$ protein corona

Engineered nanoparticles (NP) such as gold $(\mathrm{Au}) \mathrm{NP}$ have unique physicochemical properties making them beneficial for biomedical applications such as near-infrared imaging [1], drug delivery [2] and cancer therapy [3]. It is these physicochemical properties such as size and surface charge that have an effect upon biological systems [4]. Several studies reported that the biodistribution and cellular uptake of AuNP were sizedependent [5-7] but the surface properties also affected cell uptake [8-12]. AuNP with different cationic surface coatings showed diverse mechanisms of cellular uptake in HeLa and MCF10A epithelial cells [13]. Others have reported that the cell uptake mechanisms of 2, 4 and $6 \mathrm{~nm}$ AuNP were dependent on size and surface functional groups [14]. It is well-known that the interac- tive surface and fate of an NP in a biological system is determined by the biocorona. Complex proteins, ions, lipids and other macromolecules will readily adsorb onto an $\mathrm{NP}$ and these biomolecules will form the biocorona [15,16]. Therefore, cell uptake of NP may also be modulated by its biomolecular surface [17]. Our laboratory showed that with different protein coronas at physiological concentrations of albumin $(44 \mathrm{mg} / \mathrm{ml})$, $\operatorname{IgG}(14.5 \mathrm{mg} / \mathrm{ml})$ or transferrin $(3 \mathrm{mg} / \mathrm{ml})$ form NP protein complexes that significantly affected NP uptake in human epidermal keratinocytes (HEK) [18]. Particle size and surface ligand grafting density can also affect the adsorption of serum proteins and cell uptake in macrophages [19]. In the presence or absence of a protein corona, silica NP showed different uptake efficiencies [20].
Yang $\mathrm{Li}^{1}$ \&

Nancy A Monteiro-Riviere *,1 ${ }^{1}$ Nanotechnology Innovation Center of Kansas State University (NICKS), Kansas State University, Manhattan, KS, USA *Author for correspondence: nmonteiro@ksu.edu 
Yet, it is unclear how the protein corona of AuNP affects the cell uptake and its mechanisms.

The presence of serum in cell cultures may confound NP uptake by forming a serum protein corona [20]. In order to avoid this disadvantage, cryopreserved primary neonatal HEK were used as a suitable model system because they are grown in serum-free medium. HEK are epithelial cells that are an important component of innate immunity. This study provides a better understanding on how epithelial cells are involved in AuNP cell uptake and their interactions with the innate immune system thereby, providing key information on the design of smart NP to avoid being trapped within the innate immune system.

The uptake mechanisms of NP are not well-understood, however, endocytosis of NP encompasses a series of processes that depend on the size, shape and functional surface properties of the NP [6,11,21-23] which make it a more diverse and difficult process to comprehend. Although the precise mechanisms of endocytosis are unclear, the process of endocytosis occurs through multiple mechanisms and is often defined as phagocytosis (cell eating) or pinocytosis (cell drinking) [23]. Macropinocytosis is receptor independent and fluid-based, while clathrin-mediated endocytosis and nonclathrin-mediated endocytosis are considered as receptor dependent endocytosis [22-24].

The objectives of this study were to investigate cell uptake in HEK from $15 \mathrm{~min}$ to $48 \mathrm{~h}$ with 40 and $80 \mathrm{~nm}$ AuNP with lipoic acid (negatively charged), polyethylene glycol (PEG, neutral charged) and branched polyethyleneimine (BPEI, positively charged) surface coatings in the presence or absence of a human plasma (HP) or human serum albumin (HSA) protein corona and to study the inflammatory potential. In addition, different cellular uptake inhibitors were selected to characterize the mechanism of endocytosis and to gain insight on the role of the protein corona on the mechanism of cell uptake.

\section{Materials \& methods AuNP synthesis}

Biopure $^{\mathrm{TM}} 40$ and $80 \mathrm{~nm}$ lipoic, PEG and BPEIcoated AuNP were purchased from nanoComposix (CA, USA) and the synthesis was conducted by using the reduction of hydrogen tetrachloroaurate (III) in a basic solution of potassium carbonate. Tangential flow filtration was used to concentrate and wash the NP. The lipoic acid functionalized surfaces were synthesized by adding $0.2 \mathrm{mg}$ lipoic acid with $1 \mathrm{mg}$ Au. PEG functionalization was performed by adding $0.5 \mathrm{mg}$ of $5 \mathrm{kDa}$ thiol-methoxy-terminated PEG for each $1 \mathrm{mg}$ of Au. Carboxylic acid of the lipoic and the free amines on the BPEI were linked by 1-ethyl-3-(3-dimethylaminopropyl) carbodiimide coupling chemistry to synthesize the BPEI functionalized surface. After each functional group was synthesized, AuNP were washed by tangential flow filtration and filtered under sterile conditions. Then BPEI-AuNP were centrifuged to remove any residual BPEI. Endotoxin, an important biological contaminant was also evaluated in all samples and confirmed to be less than $2.5 \mathrm{EU} / \mathrm{ml}[25,26]$. All NP were stored at $4^{\circ} \mathrm{C}$ in the dark.

\section{Preparation of the protein corona on NP}

Human blood was collected from healthy donors $(n=5)$ and was obtained from the Biological Specialty Corporation (PA, USA) and shipped the same day and stored at $-80^{\circ} \mathrm{C}$. Plasma was obtained by centrifugation of the anti-coagulated blood for $10 \mathrm{~min}$ at $2500 \times \mathrm{g}$ at room temperature. The collected HP was pooled together. AuNP were incubated with $55 \% \mathrm{v} / \mathrm{v}$ human pooled plasma (HP) or $44 \mathrm{mg} / \mathrm{ml} \mathrm{HSA} \mathrm{(Sigma-Aldrich,} \mathrm{MO,}$ USA) for $1 \mathrm{~h}$ at $37^{\circ} \mathrm{C}$ in an orbital shaking incubator at $250 \mathrm{rpm}$. After incubation, the unbound and weakly associated proteins (known as soft protein corona) were removed by three repeated phosphate-buffered saline (PBS) washes, centrifuged at $16,000 \times g$ at $20^{\circ} \mathrm{C}$ for $15 \mathrm{~min}$.

\section{Nanoparticle characterization}

AuNP with and without a protein corona were fully characterized: by transmission electron microscopy (TEM) on an FEI Tecnai G2 Spirit BioTWIN TEM (FEI, OR, USA) with energy-dispersive $\mathrm{x}$-ray spectroscopy (EDX) at an accelerating voltage of $80 \mathrm{kV}$. The hydrodynamic diameter and $\zeta$-potential with the Zetasizer Nano ZS (Malvern Instruments, Worcester, UK); and ultraviolet-visible (UV-VIS) spectrophotometry on a BioTek Hybrid reader (BioTek Instruments, Inc., VT, USA). The size distribution and $\zeta$-potential were obtained with four separate measurements and each measurement counts at least ten-times. The characterization of AuNP in PBS is presented in Figure 1 \& Table 1, and the characterization of AuNP in HEK medium (serum-free condition) is presented in Supplementary Table 1.

\section{Cytotoxicity}

Cryopreserved primary neonatal HEK (Lonza, MD, USA) were cultured in KGM-Gold ${ }^{\mathrm{TM}}$ keratinocyte

Figure 1. Transmission electron microscopy and ultraviolet-visible spectra of gold nanoparticles (see facing page). Upper panel is representative of 40 and $80 \mathrm{~nm}$ AuNP; lower panel represents the size distribution profiles of 40 and $80 \mathrm{~nm}$ Lipoic, PEG and BPEI-AuNP.

AuNP: Gold nanoparticles; BPEI: Branched polyethyleneimine; PEG: Polyethylene glycol. 


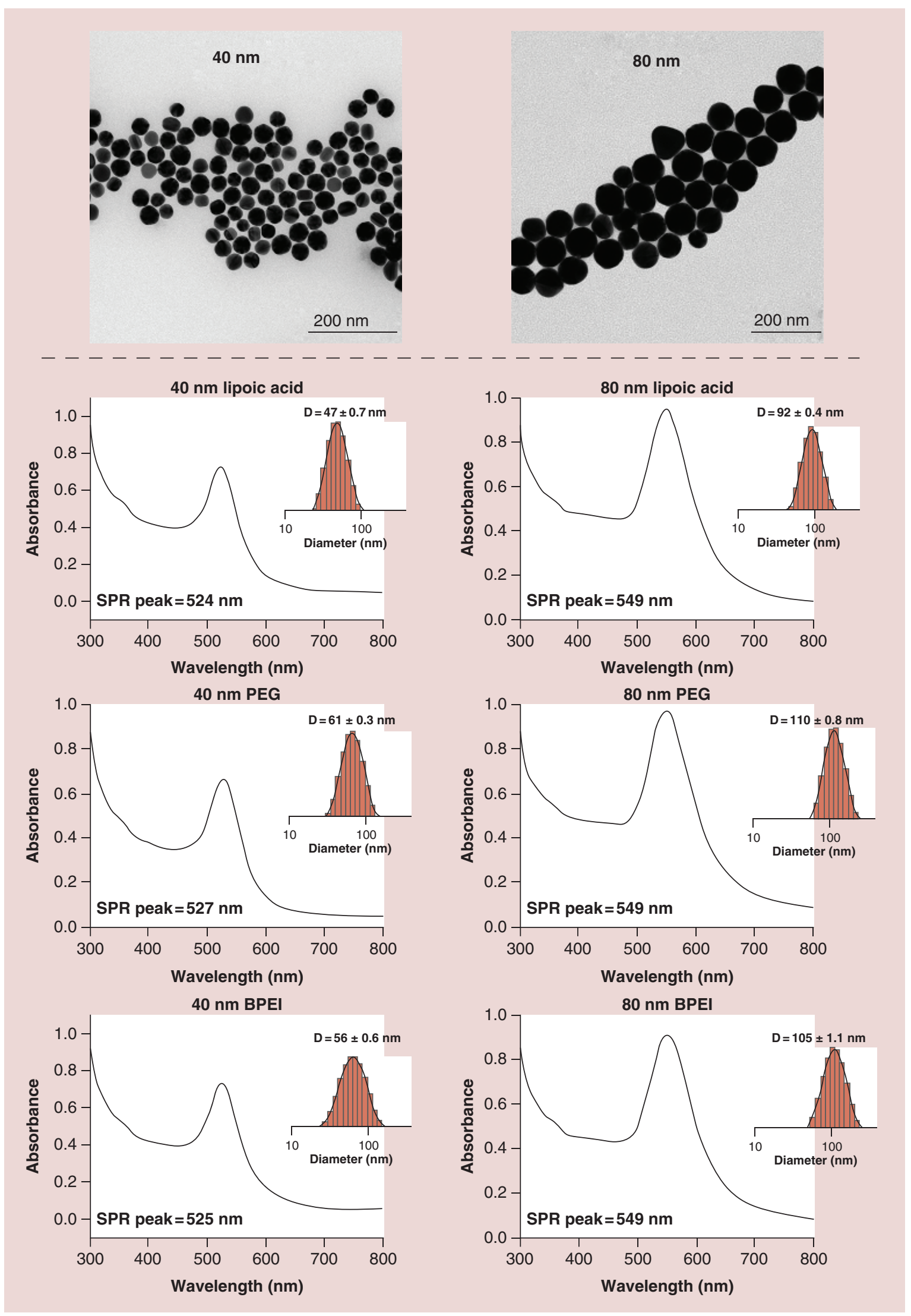


Table 1. Characterization of gold nanoparticles with and without human plasma and human serum albumin corona.

\begin{tabular}{|c|c|c|c|c|c|c|c|c|c|}
\hline \multirow[t]{2}{*}{ AuNP } & \multicolumn{3}{|l|}{ Bare } & \multicolumn{3}{|l|}{ Human plasma } & \multicolumn{3}{|c|}{ Human serum albumin } \\
\hline & $\begin{array}{l}\text { Hydrodynamic } \\
\text { diameter }(\mathrm{nm})\end{array}$ & PdI & $\begin{array}{l}\zeta \text {-potential } \\
(\mathrm{mV})\end{array}$ & $\begin{array}{l}\text { Hydrodynamic } \\
\text { diameter }(\mathrm{nm})\end{array}$ & Pdl & $\begin{array}{l}\zeta \text {-potential } \\
(\mathrm{mV})\end{array}$ & $\begin{array}{l}\text { Hydrodynamic } \\
\text { diameter }(\mathrm{nm})\end{array}$ & Pdl & $\begin{array}{l}\zeta \text {-potential } \\
(\mathrm{mV})\end{array}$ \\
\hline 40 Lipoic & 47.08 & 0.071 & -44.00 & 74.29 & 0.094 & -11.50 & 79.25 & 0.236 & -15.30 \\
\hline 40 PEG & 61.10 & 0.066 & -4.60 & 72.70 & 0.086 & -9.87 & 61.77 & 0.070 & -6.37 \\
\hline 40 BPEI & 56.43 & 0.186 & 39.20 & 296.50 & 0.305 & -14.00 & 127.10 & 0.356 & -12.30 \\
\hline 80 Lipoic & 91.67 & 0.053 & -53.60 & 131.10 & 0.083 & -12.10 & 111.90 & 0.119 & -14.50 \\
\hline 80 PEG & 109.80 & 0.057 & -3.44 & 113.50 & 0.078 & -9.73 & 112.60 & 0.019 & -7.96 \\
\hline $80 \mathrm{BPEI}$ & 105.40 & 0.112 & 46.20 & 266.40 & 0.303 & -9.26 & 188.10 & 0.295 & -9.81 \\
\hline
\end{tabular}

growth medium and expanded in T-75 flasks to $80 \%$ confluency. Cells were detached with trypsin and seeded in 96 -well black microplates $\left(0.32 \mathrm{~cm}^{2}\right.$ growth area) with 10,000 cells/well and grown overnight at $37^{\circ} \mathrm{C}$ in a humidified environment of $5 \% \mathrm{CO}_{2}$. To minimize evaporation of the culture medium, the peripheral 96-well plates were filled with PBS. Medium was replaced with fresh medium (control) or medium with different concentrations of AuNP (12.5 25, 50 and 100 $\mu \mathrm{g} / \mathrm{ml} ; \mathrm{n}=6)$. After 24 or $48 \mathrm{~h}$, HEK were washed three-times with PBS at pH 7.4 and alamar blue contained medium (1:10 volume ratio) was added to each well and cultured for $3 \mathrm{~h}$. Fluorescence was quantitated with the BioTek Hybrid reader (BioTek Instruments, Inc.) at excitation/emission of 540/590 nm. Cell viability, proportional to an increase in fluorescence, was subtracted from the fluorescence background and normalized to the controls and expressed as percent viability [27].

\section{AuNP cellular uptake in HEK}

HEK were seeded in six-well plates at a density of $2.5 \times 10^{5}$ cells $/ \mathrm{ml}$ and cultured overnight at $37^{\circ} \mathrm{C}$ in a humidified environment of $5 \% \mathrm{CO}_{2}$. Lipoic, PEG and BPEI-AuNP with or without HP or HSA protein coronas were added to HEK at $25 \mu \mathrm{g} / \mathrm{ml}$ and incubated for $0.25,0.5,1,3,6,12,24$ and $48 \mathrm{~h}$ at $37^{\circ} \mathrm{C}$. After incubation, the cells were washed three-times with PBS and then subjected to an etching process with $1 \mathrm{ml}$ iodine and potassium iodide $\left(\mathrm{I}_{2} / \mathrm{KI}: 0.34 \mathrm{mM} / 2.04 \mathrm{mM}\right)$ for 3 min [10]. After etching, cells were washed with PBS for three-times and collected for inductively coupled plasma mass spectrometry (ICP-MS).

\section{Cellular uptake mechanisms}

HEK were seeded in 12-well plates at a density of $2 \times$ $10^{5} \mathrm{cell} / \mathrm{s} / \mathrm{ml}$ and cultured overnight. Different endocytic inhibitors were first preincubated with HEK for $1 \mathrm{~h}$ in $\left[\mathrm{NaN}_{3}\right.$ (sodium azide, $10 \mathrm{mM}$, Sigma-Aldrich), 2-deox- yglucose (DOG, $50 \mathrm{mM}$, Sigma-Aldrich), sucrose (450 mM, Sigma-Aldrich), chlorpromazine hydrochloride (CPZ, $28 \mathrm{nM}$, Sigma-Aldrich), nystatin (180 nM, Sigma-Aldrich), or methyl- $\beta$-cyclodextrin $(\mathrm{M} \beta \mathrm{CD}$, $5 \mathrm{mM}$, Sigma-Aldrich)]. The concentrations used were based on previous studies [14,28,29], and the treatment with different inhibitors did not induce cytotoxicity. After preincubation with the different inhibitors, the medium was replaced, and lipoic, PEG and BPEI-AuNP with or without HP protein corona were added to HEK at $25 \mu \mathrm{g} / \mathrm{ml}$ in the presence of different inhibitors. All AuNP and AuNP with HP protein corona without inhibitors served as the control. After $3 \mathrm{~h}$ of incubation, HEK were washed with PBS and etching was conducted for $3 \mathrm{~min}$, followed by another three PBS washes and then HEK were collected for ICP-MS analysis.

\section{Temperature \& energy-dependent uptake pathways}

HEK were seeded as mentioned above and pretreated with/without $10 \mathrm{mM} \mathrm{NaN}_{3}$ and $50 \mathrm{mM} \mathrm{DOG}$ at $4^{\circ} \mathrm{C}$ or $37^{\circ} \mathrm{C}$ for $1 \mathrm{~h}$. HEK were incubated with $25 \mu \mathrm{g} / \mathrm{ml}$ with all AuNP or AuNP with a HP protein corona for $3 \mathrm{~h}$ with and without $\mathrm{NaN}_{3} / \mathrm{DOG}$ at $4^{\circ} \mathrm{C}$ or $37^{\circ} \mathrm{C}$. AuNP or AuNP with a HP protein corona without inhibitors were cultured at $37^{\circ} \mathrm{C}$ to serve as the control. After $3 \mathrm{~h}$ of incubation, HEK were washed with PBS and etched for $3 \mathrm{~min}$, then washed three-times with PBS and collected for ICP-MS.

\section{ICP-MS analysis}

Cells were collected and dried using a heat block at $90^{\circ} \mathrm{C}$ for $5 \mathrm{~h}$. Samples were digested by hydrochloric acid and nitric acid (volume ratio $3: 1$ ) at $95^{\circ} \mathrm{C}$ overnight. After digestion, each sample was diluted to $5 \mathrm{ml}$ with $1 \%$ nitric acid and $2 \%$ hydrochloric acid solution. A series of Au standards (0, 1, 10, 25, 50 and $100 \mathrm{ppb})$ were prepared each time with the samples. Samples and fresh Au standards were analyzed using the Nex- 
ION 350X ICP-MS spectrometer (Perkin Elmer, MA, USA). The Au ion concentration of the samples was quantitated relative to the Au standard curve.

Cell internalization amount of AuNP was quantified with the mass of intracellular gold that converted to the AuNP number using a reported method [30]. The internalization rate of AuNP was calculated by AuNP internalization amount that divided by incubation period. Cell uptake efficiency (\%) was normalized to cells without inhibitors.

\section{Transmission electron microscopy}

For TEM characterization of the AuNP, a drop of each type of AuNP in deionized water were placed on formvar-coated carbon grids and allowed to air dry. All AuNP were viewed on FEI Tecnai G2 Spirit BioTWIN TEM at an accelerating voltage of $120 \mathrm{kV}$.

For the uptake study, HEK were grown to $80 \%$ confluency and treated with $25 \mu \mathrm{g} / \mathrm{ml}$ of all three surface coatings of AuNP for 1 and 24 h. Following exposure, HEK were harvested with $0.05 \%$ trypsin/ EDTA, rinsed in buffer and fixed for $24 \mathrm{~h}$ in $4 \%$ formaldehyde and $1 \%$ glutaraldehyde in phosphate buffer. Cells were rinsed in $0.1 \mathrm{M}$ phosphate buffer, embedded as a pellet in $3 \%$ agar and postfixed in $1 \%$ osmium tetroxide for $1 \mathrm{~h}$, washed in buffer and centrifuged for $5 \mathrm{~min}$. All pellets were dehydrated in a graded ethanol series, cleared in acetone, infiltrated and embedded in Spurr's resin (Polysciences, Inc. PA, USA). Thin sections $(800 \AA)$ were mounted on copper grids and examined unstained on a FEI Tecnai G2 Spirit BioTWIN TEM at an accelerating voltage of $80 \mathrm{kV}$. Cells were not stained to allow for better visualization of the AuNP within the vacuoles and to ensure the absence of stain artifacts resulting from the lead citrate and uranyl acetate. TEM and scanning transmission electron microscopy (STEM) images were taken and EDX was conducted on an Oxford detector at $<135 \mathrm{eV}$.

\section{Cytokine detection}

HEK were treated with $25 \mu \mathrm{g} / \mathrm{ml}$ of each type of AuNP for 24 and 48 h. Supernatants were collected and measured for human cytokines IL-1 $\alpha$, IL-1 $\beta$ and IL-8 and quantitated by ELISA. The ELISA kits were purchased from R\&D Systems (MN, USA), and performed according to the manufacturers' instructions. The raw data were quantitated relative to the standard curve. The cytokine detection limits were: IL-1 $\alpha$ (7.8), IL-1 $\beta$ (3.9), IL-8 (31.3) $\mathrm{pg} / \mathrm{ml}$.

\section{Statistical analysis}

Mean values for each treatment were calculated and the significant differences $(\mathrm{p}<0.05)$ determined with the $F$-test and Student's $t$-test. The cell viability data are expressed as mean $\pm S D$ ( $n=5$ wells/treatment) and the cytokine and cell uptake data as mean $\pm S D(n=3$ wells/treatment).

\section{Results \& discussion}

\section{Characterization of AuNP}

All 40 and $80 \mathrm{~nm}$ lipoic acid, PEG and BPEI-coated AuNP were characterized by TEM, UV-VIS spectrophotometry and Zetasizer analysis (Figure 1 \& Table 1). After a 1-h incubation with HP or HSA, the protein corona-coated AuNP were recharacterized and showed an increase in size with all three surface coatings (Table 1). A protein corona surrounding a AuNP was observed by TEM (Supplementary Figure 1) similar to what was reported by our laboratory [31]. The hydrodynamic diameters of AuNP were generally larger than the core particle size noted by TEM. After the AuNP were exposed to HP and HSA protein coronas, the hydrodynamic diameters increased and the Z Z-potential had a slight negative charge (Table 1). The hydrodynamic diameters of AuNP exposed to the cell culture medium can be seen in Supplementary Table 1. All NP were screened for endotoxins because it is a common biological contaminant that can interfere with the biological effects of NP [25,26,32].

\section{Cytotoxicity of AuNP}

To assess the cytotoxicity of AuNP in HEK, the HEK were exposed to various concentrations ranging from 12.5, 25, 50 and $100 \mu \mathrm{g} / \mathrm{ml}$ of AuNP for 24 and $48 \mathrm{~h}$. Figure 2A-D depicts the toxicity of 40 and $80 \mathrm{~nm}$ lipoic, PEG and BPEI-coated AuNP which showed no toxicity with most coatings at $12.5 \mu \mathrm{g} / \mathrm{ml}$ and $25 \mu \mathrm{g} / \mathrm{ml}$. However, the $50 \mu \mathrm{g} / \mathrm{ml}$ and $100 \mu \mathrm{g} / \mathrm{ml}$ of 40 and 80 $\mathrm{nm}$ BPEI-AuNP showed a dose dependent toxicity at $24 \mathrm{~h}$; while at $48 \mathrm{~h}$ the $40 \mathrm{~nm}$ lipoic and BPEI-AuNP and $80 \mathrm{~nm}$ PEG and BPEI-AuNP showed a decrease in cell viability. These results were not surprising because most NP will show a decrease in cell viability at high concentrations at $24 \mathrm{~h}$ and a more exacerbated response by $48 \mathrm{~h}$. Therefore, the nontoxic concentration of $25 \mu \mathrm{g} / \mathrm{ml}$ was selected to study cell uptake.

\section{Cell uptake of AuNP in HEK}

HEK were exposed to the nontoxic dose of $25 \mu \mathrm{g} / \mathrm{ml}$ of bare 40 and $80 \mathrm{~nm}$ lipoic, PEG and BPEI-coated AuNP from $15 \mathrm{~min}$ to $48 \mathrm{~h}$. Cells were washed and etched with $1 \mathrm{ml} \mathrm{I} / \mathrm{KI}(0.34 \mathrm{mM} / 2.04 \mathrm{mM})$ for 3 min to remove the surface bound AuNP [10]. This procedure ensures that all $\mathrm{Au}$ ions are released from the intracytoplasmic vacuoles of the HEK and measured by ICP-MS. Two different methods were used to show the cell uptake results: the uptake rate (uptake amount per hour) seen in Figure 3 by profiling the 


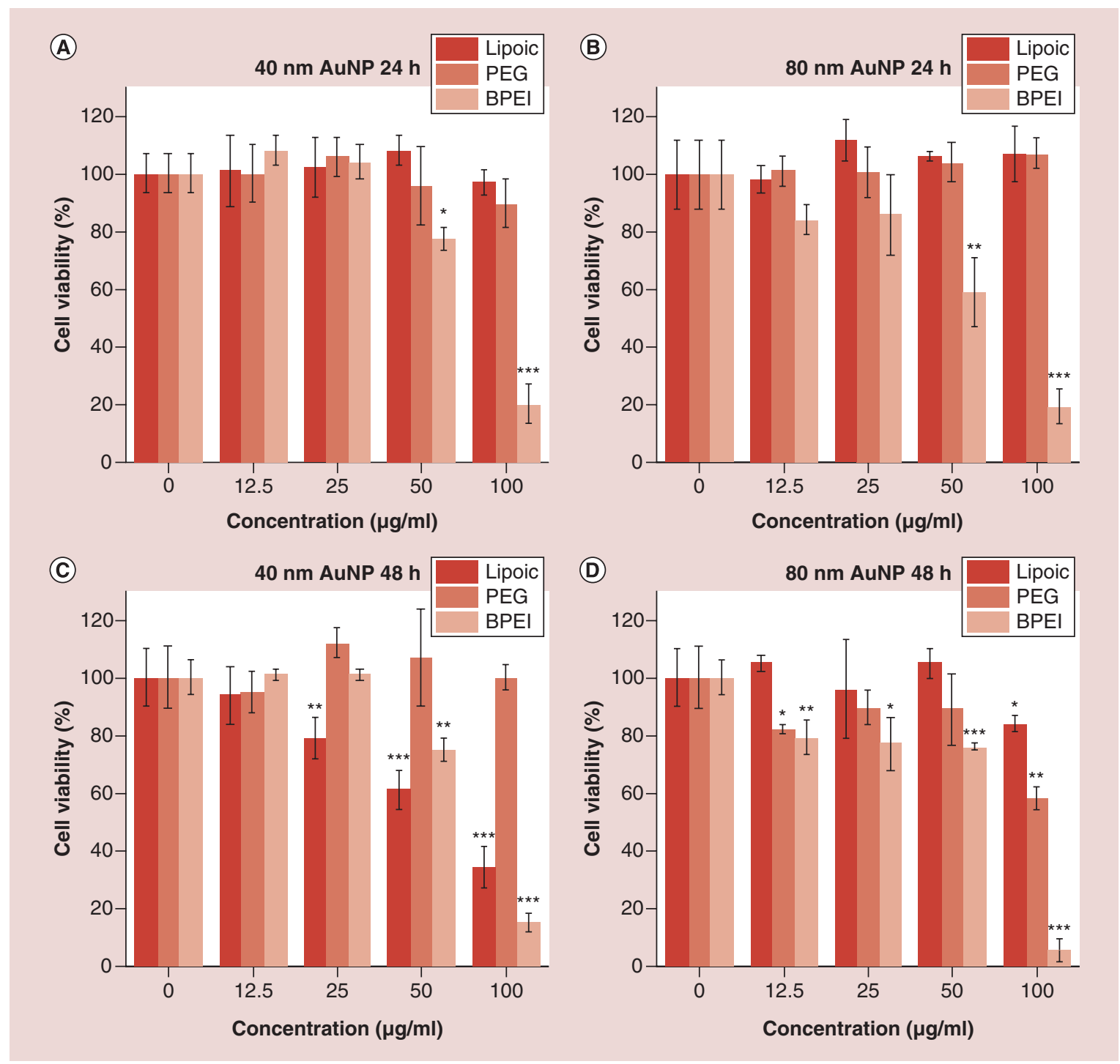

Figure 2. Cell viability of 40 and $80 \mathrm{~nm}$ lipoic acid, polyethylene glycol and branched polyethyleneimine-coated gold nanoparticles in human epidermal keratinocytes at 12.5, 25, 50 and $100 \mu \mathrm{g} / \mathrm{ml}$ for 24 and $48 \mathrm{~h}$. $40 \mathrm{~nm}$ AuNP at $24 \mathrm{~h} \mathrm{(A)} \mathrm{and} 48 \mathrm{~h}(\mathrm{C}) ; 80 \mathrm{~nm}$ AuNP at $24 \mathrm{~h}$ (B) and $48 \mathrm{~h}$ (D). Data represent as mean \pm SD ( $\mathrm{n}=5$ wells/treatment). ${ }^{*} p<0.05, * * p<0.01, * * * p<0.001$ as AuNP versus control.

AuNP: Gold nanoparticles; BPEI: Branched polyethyleneimine; Lipoic: Lipoic acid; PEG: Polyethylene glycol.

characteristics of the uptake of 40 and $80 \mathrm{~nm} \mathrm{NP}$ and the ability of HP and HSA protein coronas on cell uptake profiles. The uptake accumulative amounts overtime seen in Figure 4, which compares the different uptake amounts of bare, HP and HSA coronacoated AuNP. Figure 3A-C \& Figure 4 (black square) show the internalization rate and amount of the lipoic, PEG and BPEI-AuNP in HEK. Not surprisingly, PEG-AuNP showed the least uptake in HEK compared with the lipoic and BPEI coatings. This may be due to the neutral surface charge that minimized the cell uptake $[8,33]$. As expected, the BPEI-AuNP had the greatest cell uptake presumably due to its positive charge which increases the interaction between the BPEI-AuNP and the HEK's membrane, thereby promoting an increase in cell uptake [10]. The $40 \mathrm{~nm}$ lipoic and BPEI-AuNP with charged surfaces showed an increase in uptake compared with the $80 \mathrm{~nm}$ lipoic and BPEI-AuNP (Figure 3A \& C; Figure 4B, C, E \& F). In contrast, the $40 \mathrm{~nm}$ PEG-AuNP with a neutral charge showed less internalization than the $80 \mathrm{~nm}$ PEGAuNP (Figure 3B, Figure 4A \& D). The internalization rate of AuNP showed a decrease with lipoic and BPEI coatings over time, while PEG showed an increase after $1 \mathrm{~h}$ (Figure 3A-C). This suggests that if AuNP are used for drug delivery or cancer therapy by direct injection into the target tissue, charged AuNP and especially the BPEI-coated NP will be more effective. However, 
if PEG-AuNP are used, then the route and time of administration becomes important since a rapid influx of AuNP was noted at later time points.

\section{Ultrastructural localization of AuNP}

TEM depicted the intracellular localization of bare AuNP within cytoplasmic vacuoles in HEK (Figure 5). At $1 \mathrm{~h}$, most 40 and $80 \mathrm{~nm}$ AuNP were localized within the endocytic/cytoplasmic vesicles close to the periphery of the cell membrane with the exception of 40 and $80 \mathrm{~nm}$ PEG-AuNP. It was very difficult to view PEG-AuNP within HEK but after searching several cells, only one cell in both the 40 and $80 \mathrm{~nm}$ AuNP had AuNP at $1 \mathrm{~h}$. At $24 \mathrm{~h}$, most AuNP were localized adjacent to the nucleus but were never noted within the nucleus. In Figure 5, the TEM micrographs showed 40 and $80 \mathrm{~nm}$ BPEI-AuNP in contact with the outer cell membrane at $1 \mathrm{~h}$ but less was noted with the $80 \mathrm{~nm}$ BPEI-AuNP compared with the $40 \mathrm{~nm}$ BPEI-AuNP. Both 40 and $80 \mathrm{~nm}$ PEG-AuNP were rarely located within the cytoplasm at $1 \mathrm{~h}$, but more AuNP were present at $24 \mathrm{~h}$. The amount of $40 \mathrm{~nm}$ PEG-AuNP noted by TEM was less when compared to the 40 and $80 \mathrm{~nm}$ lipoic, BPEI and $80 \mathrm{~nm}$ PEG-AuNP at $24 \mathrm{~h}$, which is consistent with the ICP-MS data. Our STEM image allowed us to get an overall intracellular view of the location of the AuNP within the cell (Supplementary Figure 2). The $40 \mathrm{~nm}$ BPEI-AuNP were in close proximity to the outer cell membrane at $1 \mathrm{~h}$. Over time, endocytosis of the AuNP showed several $40 \mathrm{~nm}$ BPEI-AuNP agglomerates surrounding the nucleus at $24 \mathrm{~h}$ (Supplementary Figure 2). Using EDX, $40 \mathrm{~nm}$ BPEI-AuNP (Supplementary Figure 2) showed an increase in AuNP within the cytoplasm of HEK and EDX verified the element to be Au.

Protein corona can inhibit AuNP uptake in HEK Pooled sodium citrate human blood plasma (HP) $(55 \% \mathrm{v} / \mathrm{v})$ and physiological concentrations of HSA $(44 \mathrm{mg} / \mathrm{ml})$ were added to all AuNP in an orbital shaking incubator for $1 \mathrm{~h}$ to aid in the formation of the corona over the AuNP. Protein corona effects on AuNP cell uptake are illustrated in Figure 4. In all cases, HP protein corona reduced AuNP uptake with all three surface coatings. These results were similar to that reported by others and in our laboratory with silver NP [18] which showed a decrease in NP cell uptake in the presence of plasma or serum [9,14,34]. Figure 4, showed a similar and consistent amount of AuNP cell uptake in HEK over time with HP-AuNP, except for 40 and $80 \mathrm{~nm}$ BPEI-AuNP which showed an increase immediately but remained relatively consistent over time. Also, the $80 \mathrm{~nm}$ PEG-AuNP with an HP corona showed an increase in uptake at $12 \mathrm{~h}$.
HSA has been reported to be one of the most adsorbed proteins to NP [35,36]. The HSA corona in Figure 4 showed a decreased in AuNP cell uptake similar to the HP corona, in particular with the 40 and $80 \mathrm{~nm}$ BPEI-AuNP which showed a consistent but minimal cell uptake over time (Figure 4C \& F). However, HSA caused a slight increase in uptake at 24 and $48 \mathrm{~h}$ for all lipoic-AuNP and PEG-AuNP. Figure 3D-I, shows the internalization rate of AuNP with HP and HSA protein coronas in which similar patterns were noted. However, comparing the internalization rate of both the HP and HSA protein coronas and bare NP, the coronas on the lipoic-AuNP altered the internalization rate of 40 and $80 \mathrm{~nm}$ AuNP. The $80 \mathrm{~nm}$ corona-coated lipoic-AuNP showed greater internalization compared to the $40 \mathrm{~nm}$ corona-coated lipoic-AuNP (Figure 3A, D \& G). In all cases, the internalization rate of the protein coronas of AuNP showed a decrease in cellular uptake compared to the bare NP, except for HSA-coated PEG-AuNP.

\section{HP protein corona alters the endocytic uptake} It has been reported that the surface properties can modulate the protein corona and alter the cellular uptake efficiency [18-20]. Therefore, it is logical to suspect that in the presence of a protein corona, the cell uptake pathways selected may be affected. Therefore, AuNP endocytic pathways were investigated with HEK in the absence or presence of an HP protein corona.

Energy-dependent endocytic pathway of AuNP in the absence or presence of a protein corona

Energy-dependent endocytic pathways may be suppressed at low temperatures (low metabolism) and ATP depletion with sodium azide and 2-deoxyglucose as inhibitors [28]. In Figure 6A \& C, all bare AuNP showed a reduction in cell uptake in the presence of ATP depletion agents or at low temperatures $\left(4^{\circ} \mathrm{C}\right)$ except for the $40 \mathrm{~nm}$ lipoic-AuNP. The surface coatings of $40 \mathrm{~nm}$ AuNP significantly affected the energydependent endocytic pathways. These results suggest that BPEI-AuNP with a positive charge was energydependent, while PEG-AuNP with a neutral charged surface was less energy dependent because it showed less of a decrease in cell uptake compared to BPEIAuNP. However, the negatively charged lipoic-AuNP was energy nondependent. The $40 \mathrm{~nm}$ lipoic-AuNP may be internalized by macropinocytosis which is a nonspecific endocytotic pathway [23], or another possibility would be that it could directly traverse through the cell membrane and into the cytoplasm of the cell due to its small size and same surface charge as the cell membrane. In contrast, the $80 \mathrm{~nm}$ AuNP with negative, neutral and positive surfaces all showed an energy-dependent endocytosis. 

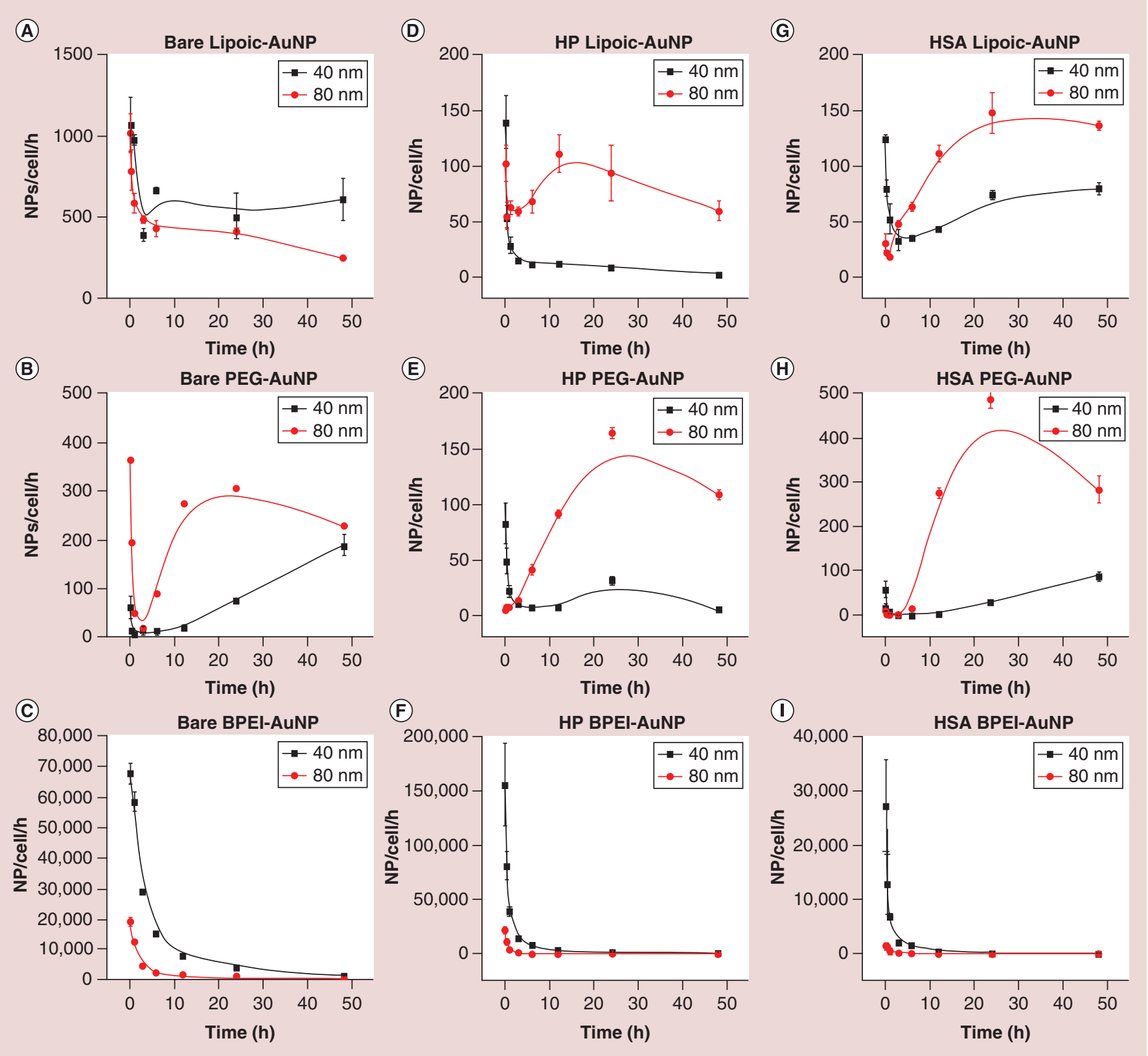

Figure 3. The internalization rate of 40 and $80 \mathrm{~nm}$ gold nanoparticles in human epidermal keratinocytes over time. Human epidermal keratinocytes were exposed to $25 \mu \mathrm{g} / \mathrm{ml}$ of 40 and $80 \mathrm{~nm}$ AuNP in the presence or absence of HP corona or HSA corona from 0.25 to $48 \mathrm{~h}$. Cell uptake was analyzed by ICP-MS and the internalization rate (uptake number/h) was calculated. (A-C) Bare Lipoic, PEG and BPEI-AuNP; (D-F) HP-coated Lipoic, PEG and BPEI-AuNP; (G-I) HSA-coated Lipoic, PEG and BPEI-AuNP. Data represent as mean \pm SD ( $n=3$ wells/treatment).

AuNP: Gold nanoparticles; BPEI: Branched polyethyleneimine; HP: Human plasma; HSA: Human serum albumin; Lipoic: Lipoic acid; NP: Nanoparticle; PEG: Polyethylene glycol.

The HP protein corona of AuNP significantly affected the uptake ratio and mechanisms in HEK. Although BPEI-AuNP with a HP corona was still mediated by an energy-dependent endocytosis, the uptake ratio was less compared to bare AuNP, which signifies that BPEIAuNP with a HP corona (Figure 6B \& D) can be internalized with less energy. The effect was similar to the
40 and $80 \mathrm{~nm}$ PEG-AuNP and $80 \mathrm{~nm}$ lipoic-AuNP. However, the bare $40 \mathrm{~nm}$ lipoic-AuNP was nonenergydependent, and it is not surprising to find that the HP corona could alter the $40 \mathrm{~nm}$ lipoic-AuNP to become energy-dependent. These results showed that the uptake of the HP protein corona of $40 \mathrm{~nm}$ lipoic-AuNP could be partially blocked by ATP depletion. 
(A)

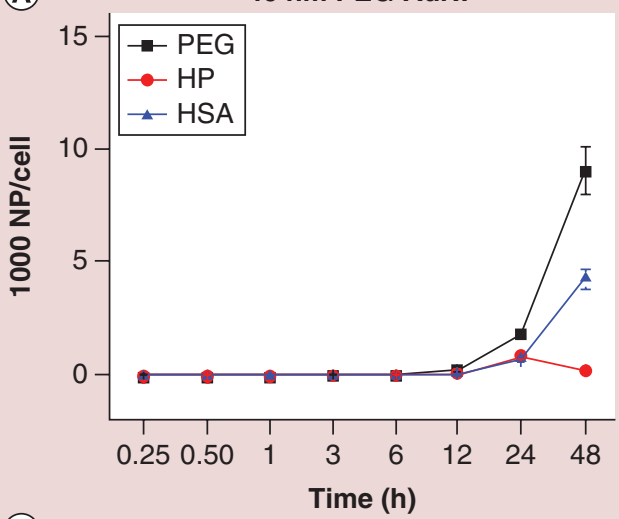

B) $40 \mathrm{~nm}$ Lipoic-AuNP

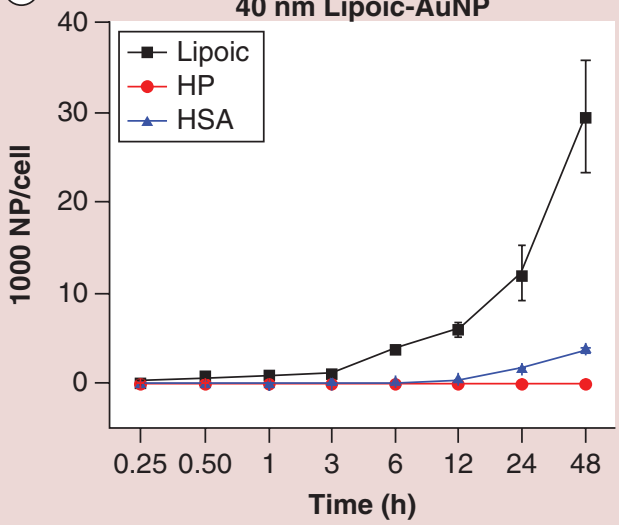

(C)

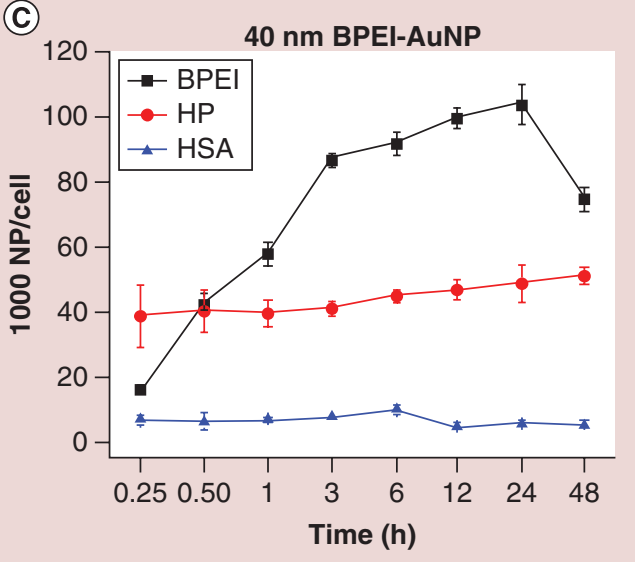

(D) $80 \mathrm{~nm}$ PEG-AUNP

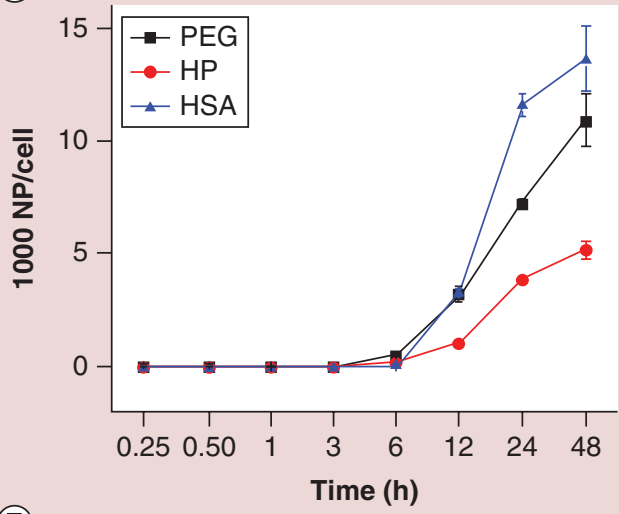

(E)

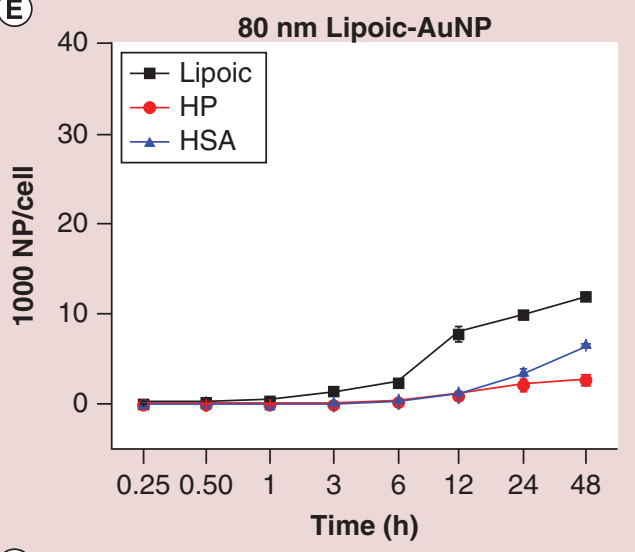

(F)

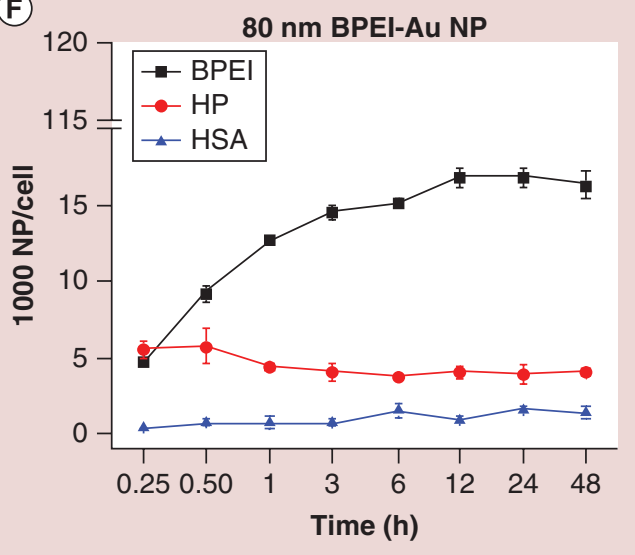

Figure 4. Cell uptake of gold nanoparticles in the presence or absence of a protein corona. Human epidermal keratinocytes were exposed to $25 \mu \mathrm{g} / \mathrm{ml}$ of $40 \mathrm{~nm}$ (left panel) and $80 \mathrm{~nm}$ (right panel) AuNP in the presence or absence of HP corona or HSA corona ranging from 0.25 to $48 \mathrm{~h}$. (A-C) $40 \mathrm{~nm}$ PEG, Lipoic and BPEI-AuNP; (D-F) $80 \mathrm{~nm}$ PEG, Lipoic and BPEI-AuNP. Data represent as mean \pm SD ( $n=3$ wells/treatment).

AuNP: Gold nanoparticles; BPEI: Branched polyethyleneimine; HP: Human plasma; HSA: Human serum albumin; Lipoic: Lipoic acid; NP: Nanoparticle.

Mechanisms of receptor-mediated endocytosis of AuNP in the absence or presence of a protein corona

Clathrin and nonclathrin-mediated endocytosis all fall into a receptor-mediated internalization pathway. In order to understand how AuNP become internalized into the cell and how the protein corona affects these uptake pathways, a set of endocytic inhibitors were used to determine the mechanisms of endocytosis of AuNP in the absence or presence of an HP protein corona.

Clathrin is a protein and clathrin-coated pits are found in regions of the cell membrane specialized in receptor- 
(A)
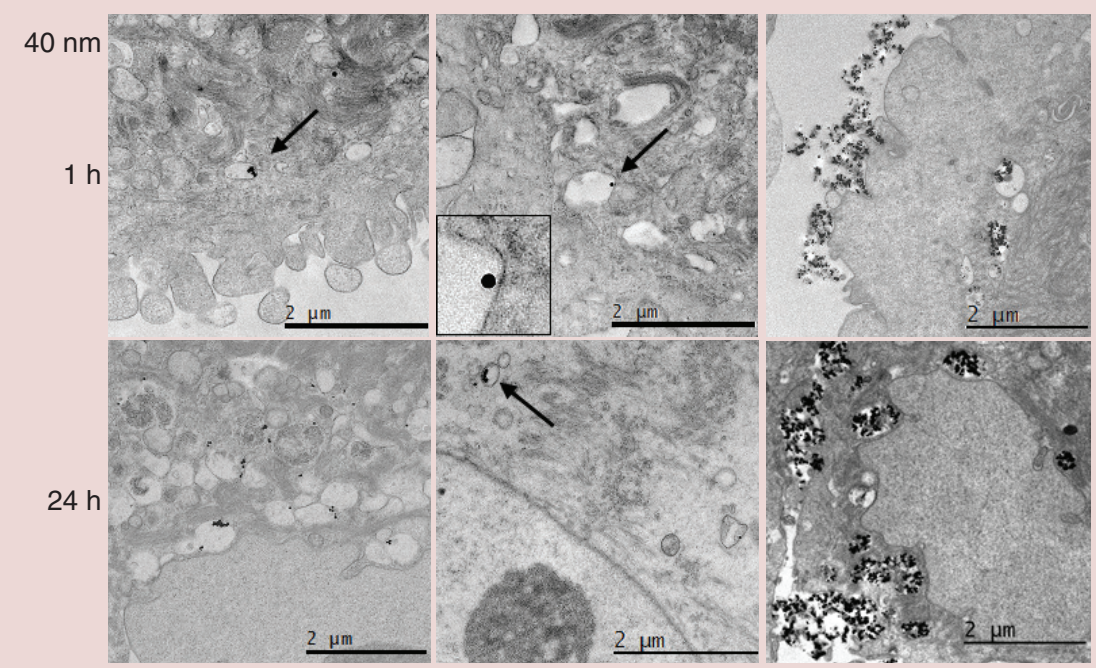

(B)

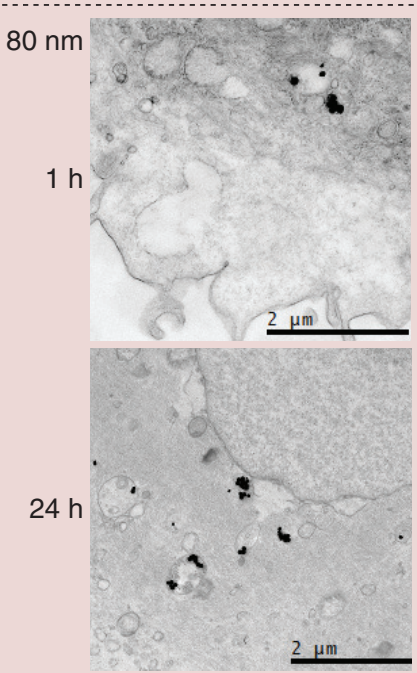

Lipoic

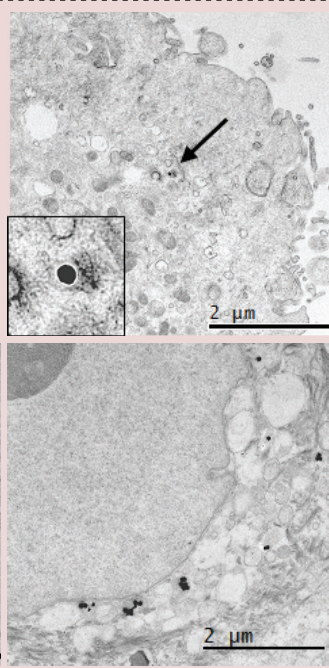

PEG

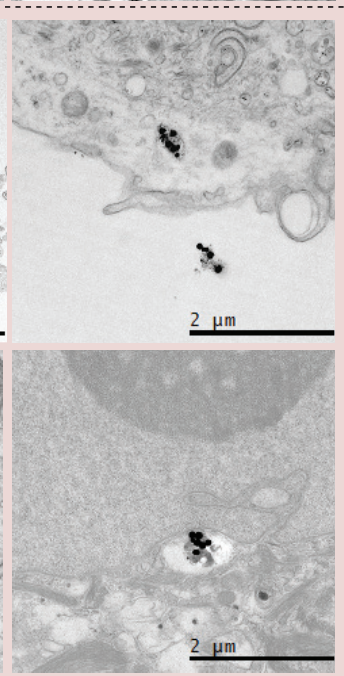

BPEI

Figure 5. Transmission electron micrographs depicting Lipoic acid, polyethylene glycol and branched polyethyleneimine-coated gold nanoparticles in human epidermal keratinocytes at $\mathbf{1}$ and $\mathbf{2 4} \mathrm{h}$. Human epidermal keratinocytes were exposed to $25 \mu \mathrm{g} / \mathrm{ml}$ of 40 and $80 \mathrm{~nm}$ Lipoic, PEG and BPEl-gold nanoparticles (AuNP) for 1 and $24 \mathrm{~h}$. The inset in the 40 and $80 \mathrm{~nm}$ PEG at $1 \mathrm{~h}$ depicts a higher magnification of a single AuNP (Scale bar $=2 \mu \mathrm{m})$. BPEI: Branched polyethyleneimine; Lipoic: Lipoic acid; PEG: Polyethylene glycol.

mediated endocytosis. They are formed by invaginations of the cell membrane within minutes which then gets pinched off to form a clathrin-coated vesicle which can fuse with early endosomes [23]. Clathrin-mediated endocytosis has been studied with CPZ and sucrose as inhibitors in HEK, HeLa and other cells [29,37-39]. Sucrose provides a hypertonic condition preventing the interaction of clathrin and adaptors by inhibiting the formation of shallow-coated pits (type I-coated pits) or receptor clustering; while $\mathrm{CPZ}$ can specifically inhibit clathrin medicated pathways by inhibiting the progression from type II-coated pits to type III-coated pits [40]. Figure 7A \& C shows 40 and $80 \mathrm{~nm}$ BPEI-AuNP were inhibited significantly in the presence of clathrin inhibi- tors without size dependency. A slight inhibitory effect was observed with $40 \mathrm{~nm}$ lipoic-AuNP but the presence of these clathrin inhibitors significantly inhibited 80 nm lipoic-AuNP. PEG-AuNP showed similar effects to lipoic-AuNP, which depicted that $80 \mathrm{~nm}$ PEG-AuNP were inhibited by clathrin inhibitors, but no effects were detected with the $40 \mathrm{~nm}$ PEG-AuNP.

The mechanisms of clathrin independence internalization are considered to be through nonclassic endocytic pathways which are very sensitive to cholesterol depletion [24]. This is commonly known as lipid raftmediated endocytosis which can be divided further as caveolae-dependent and caveolae-independent [41]. Lipid rafts provide a platform and several types of receptors, 
adaptors, regulators and other proteins can act as signaling complexes to mediate endocytosis [29]. Caveolae (50$80 \mathrm{~nm}$ ) are flask-shaped invaginations of the cell membrane that are conferred by caveolin and are an integral membrane protein [29]. Caveolin is a dimeric protein that binds cholesterol, inserts into the plasma membrane as a loop and self-associates to form a caveolin coat on the membrane invaginations [23,42]. Caveolae-independent endocytosis is not fully understood, however, it requires a 'raft' for internalization and may be defined as raft- $/$ noncaveolae-mediated endocytosis [23].

Cholesterol depletion agents, nystatin and $\mathrm{M} \beta \mathrm{CD}$, were used to investigate lipid raft-mediated pathways of AuNP [23,43-45]. In the presence of nystatin, caveolae-mediated endocytosis was inhibited which significantly decreased cell uptake of 40 and $80 \mathrm{~nm}$ lipoic and BPEI-AuNP but had no effect on the 40 and $80 \mathrm{~nm}$ PEG-AuNP. Since M $\beta C D$ alters cholesterol- rich domains of the cell membrane, treatment with $\mathrm{M} \beta \mathrm{CD}$ in HEK can inhibit the lipid raft-mediated endocytosis pathways (both caveolae and noncaveolae pathways), which decreases the cell uptake of all AuNP (Figure 7A \& C). Therefore, the uptake of 40 and $80 \mathrm{~nm}$ PEG-AuNP had no effect with caveolae inhibitors but caused a reduction in lipid raft inhibitors. The 40 and $80 \mathrm{~nm}$ PEG-AuNP were primarily internalized by caveolae-independent raft-mediated endocytosis.

In addition, the endocytic mechanisms were investigated in the presence of HP protein corona (Figure 7B \& D) which showed alterations in the internalization pathway of $40 \mathrm{~nm}$ PEG-AuNP from a raft/noncaveolae pathway to a clathrin-mediated pathway, even though there was only a $30 \%$ decrease of cell uptake in the presence of inhibitors. Also, it caused inhibition of the raft-/noncaveolae-mediated endocytic pathway with $80 \mathrm{~nm}$ PEGAuNP. For the 40 and $80 \mathrm{~nm}$ lipoic and BPEI-AuNP,
(A)

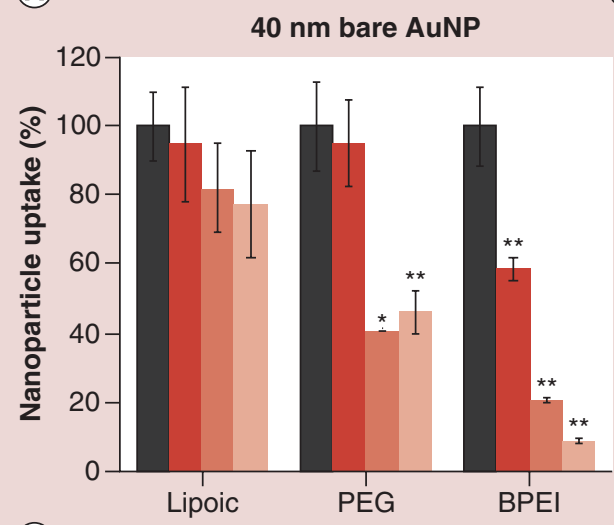

(C)

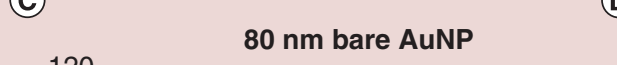

(B)

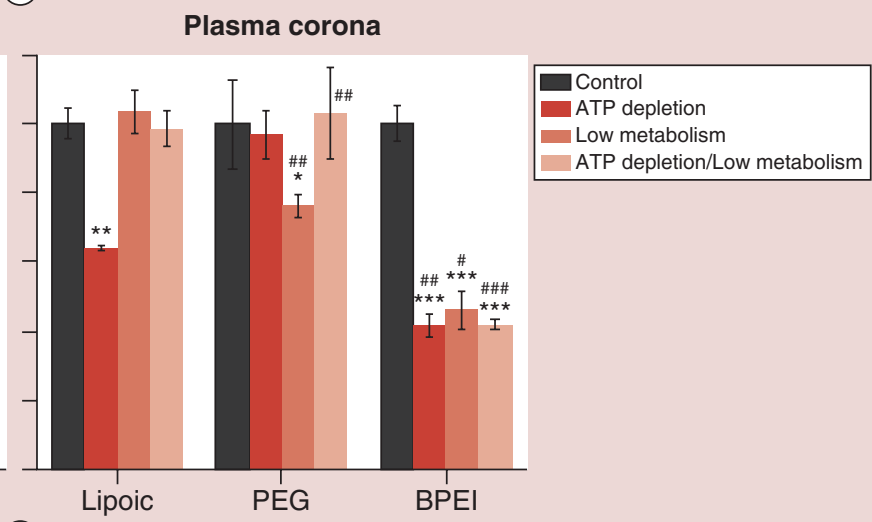

(D)
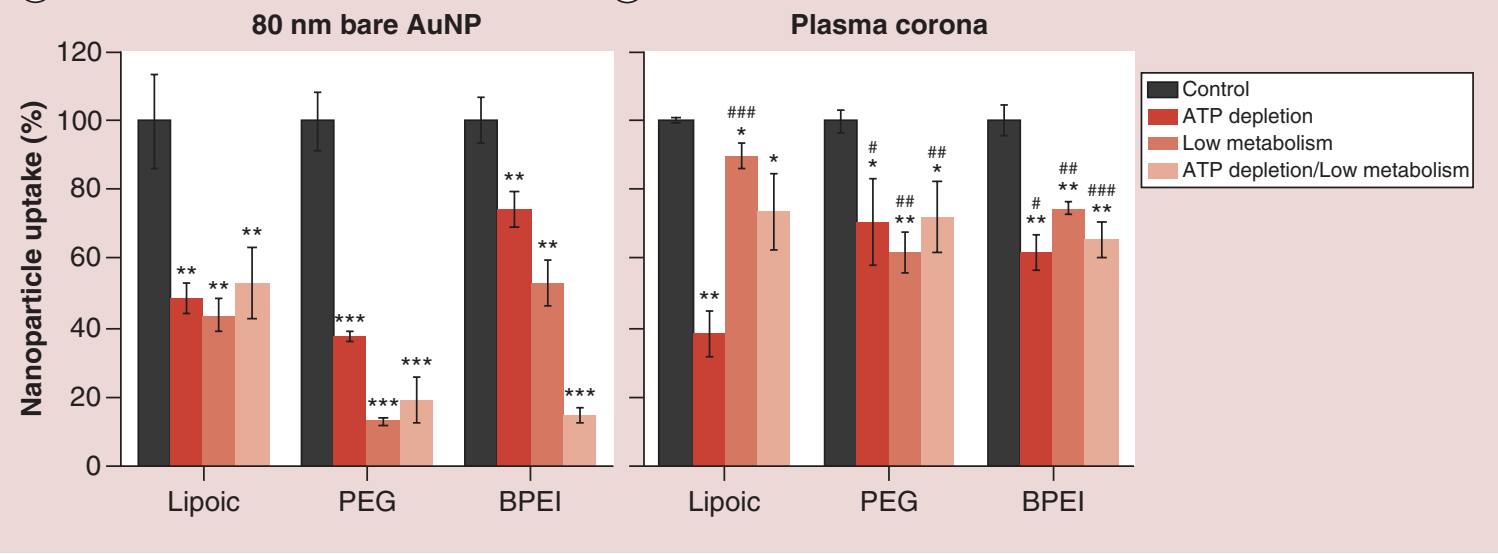

Figure 6. Energy-dependent endocytosis of 40 and $80 \mathrm{~nm}$ Lipoic, polyethylene glycol and branched polyethyleneimine-coated gold nanoparticles in the absence or presence of a human plasma protein corona. Human epidermal keratinocytes were treated with $25 \mu \mathrm{g} / \mathrm{ml}$ of $40 \mathrm{~nm}$ (A \& B) and $80 \mathrm{~nm}$ (C \& D) AuNP in the absence (A \& C) or presence (B \& D) of human plasma corona. Cell uptake efficiency (\%) was normalized to cells without inhibitors. Data are presented as mean \pm SD ( $n=3$ wells/treatment).

$* p<0.05, * * p<0.01, * * * p<0.001$ inhibitor treatment versus normalized controls.

$\# p<0.05, \# p<0.01, \# \# p<0.001$ with a protein corona AuNP versus bare AuNP without a protein corona. AuNP: Gold nanoparticles; BPEI: Branched polyethyleneimine; Lipoic: Lipoic acid; PEG: Polyethylene glycol. 
(A)

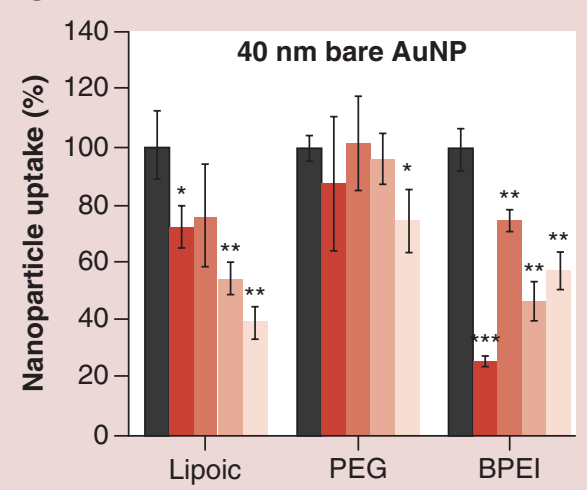

(C)

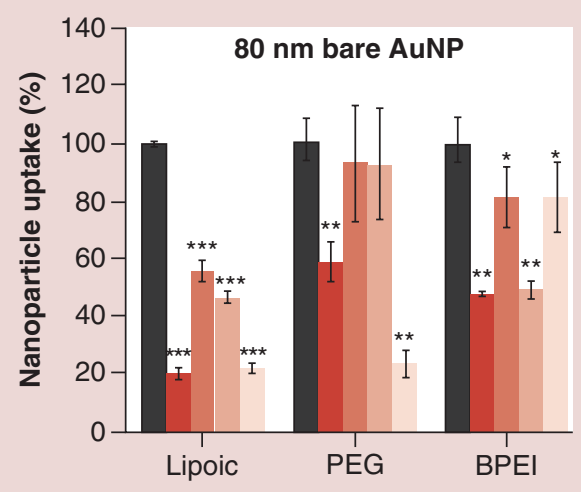

(B)

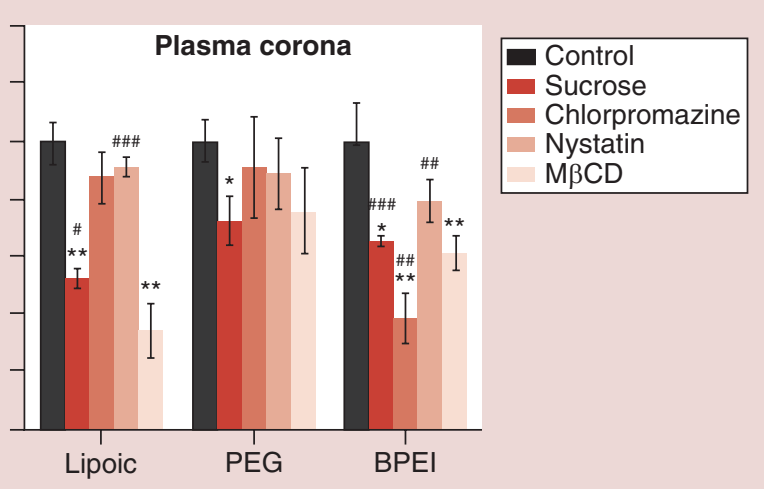

(D)

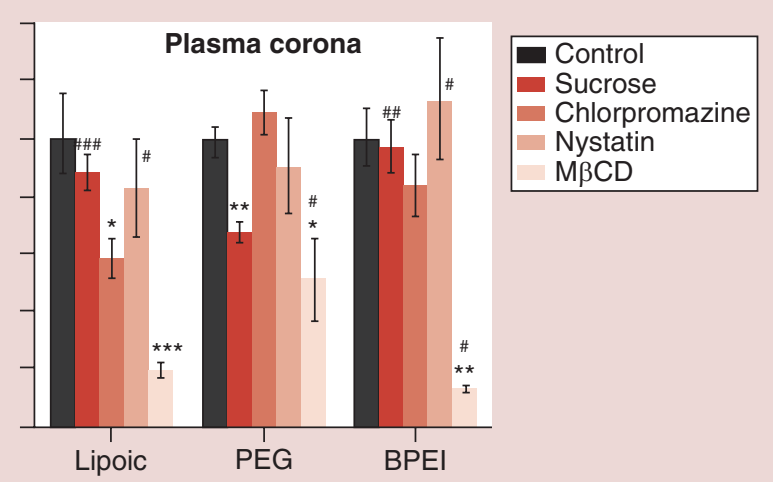

Figure 7. Endocytic mechanisms of gold nanoparticles in the absence or presence of a human plasma protein corona. Human epidermal kerationcytes were exposed to endocytic inhibitors and treated with $25 \mu \mathrm{g} / \mathrm{ml}$ of $40 \mathrm{~nm}$ (A \& B) and $80 \mathrm{~nm}$ (C \& D) AuNP in the absence (A \& C) or presence (B \& D) of a plasma protein corona. Cellular uptake efficiency (\%) was normalized to cells without inhibitors. Data are presented as mean \pm SD $(n=3$ wells/ treatment).

${ }^{*} p<0.05, * * p<0.01, * * * p<0.001$ with inhibitors versus normalized controls.

$\# \mathrm{p}<0.05, \# \mathrm{p}<0.01, \# \# \mathrm{p}<0.001$ with a protein corona AuNP versus bare AuNP without a protein corona.

AuNP: Gold nanoparticles; BPEI: Branched polyethyleneimine; Lipoic: Lipoic acid; M $\beta C D$ : Methyl- $\beta$-cyclodextrin; PEG: Polyethylene glycol.

the caveolae-mediated endocytosis was eliminated in the presence of a HP protein corona and only a raft-I noncaveolae-mediated endocytosis existed. However, clathrin-mediated endocytosis usually are not affected in the presence of a HP protein corona (some inhibition effects were noted; Figure 7) with the exception of the $80 \mathrm{~nm}$ BPEI-AuNP which showed a nonclathrindependent endocytosis with the HP corona. The HP corona of $80 \mathrm{~nm}$ BPEI-AuNP significantly reduced the clathrin and caveolae-mediated endocytosis, while the raft-/noncaveolae-mediated endocytosis increased. HP corona of $40 \mathrm{~nm}$ BPEI-AuNP had little effect on the cell uptake pathways. Clathrin-mediated endocytosis was still the primary cell uptake pathway for the $40 \mathrm{~nm}$ BPEI-AuNP with a HP protein corona, while caveolaemediated endocytosis was inhibited in the presence of a HP corona. The $40 \mathrm{~nm}$ lipoic-AuNP with a HP corona was mediated by clathrin and raft/noncaveolae medi- ated internalization, while the HP corona for the $80 \mathrm{~nm}$ lipoic-AuNP decreased clathrin and caveolae-mediated internalization which suggests that raft-/noncaveolaemediated endocytosis was the primary pathway.

\section{Summary of cellular endocytic mechanisms}

In summary, Table 2 provides a list of inhibitors used to dose the HEK in order to determine the AuNP primary endocytic cell uptake pathways. Figure 8 is a schematic diagram depicting all lipoic, PEG and BPEIAuNP internalization pathways. The 40 and $80 \mathrm{~nm}$ lipoic and BPEI-AuNP were internalized by clathrin or lipid raft-mediated endocytosis. Moreover, the $40 \mathrm{~nm}$ lipoic-AuNP can also be internalized by energyindependent fluid-based pathway, directly penetrating into the cells or through macropinocytosis. HP protein corona of these AuNP caused some effect on the clathrin-mediated endocytosis because the inhibitors par- 
tially blocked the pathway, except for the $80 \mathrm{~nm}$ BPEIAuNP which showed that the HP corona inhibited the clathrin pathway. Moreover, the HP corona inhibited the caveolae-mediated internalization with all lipoic and BPEI-AuNP. However, the 40 and $80 \mathrm{~nm}$ PEGAuNP showed a different uptake mechanism. The raft-/noncaveolae-mediated endocytosis dominated the $40 \mathrm{~nm}$ PEG-AuNP internalization. It showed that the cell uptake can vary to clathrin-mediated endocytosis in the presence of a protein corona. The $80 \mathrm{~nm}$ PEG-AuNP was internalized by clathrin and raft- $/$ noncaveolae-mediated endocytosis and the HP corona had no effect on the uptake pathways.

\section{Proinflammatory effects of HEK with AuNP}

The inflammatory effects of AuNP were also evaluated with the 'nontoxic' concentration of $25 \mu \mathrm{g} / \mathrm{ml}$ so that the response will not cause cell death but may interfere with other physiological functions and induce additional cell responses $[46,47]$. In the innate defensive response, the release of chemokines and cytokines is a key step for its role in recruiting neutrophil chemotaxis and as a chemoattractant for $T$ cells and basophils which all play a role in the development of inflammation but does not necessary lead to cell death. Figure 9 shows only the 40 and $80 \mathrm{~nm}$ BPEI-AuNP-induced IL- $1 \alpha$ at 24 and $48 \mathrm{~h}$ and some IL-1 $\beta$ secretion.

IL-1 $\alpha$ is a dual-function cytokine that acts as an alarmin and is constitutively expressed in the cytoplasm of epithelial cells [48]. The N-terminal of proIL-1 $\alpha$ contains a nuclear localization sequence which can translocate to the nucleus of cells to perform regulatory functions [49]. However, it can be released into the microenvironment upon danger and recruit other innate immune cells such as monocytes and neutrophils to the inflamed tissue to initiate an inflammatory process [50,51,52]. The 40 and $80 \mathrm{~nm}$ BPEI-AuNP induced a proinflammatory effect in HEK (Figure 9A). This might be due to the increase in cell uptake of BPEIAuNP in HEK at 24 and $48 \mathrm{~h}$ leading to HEK being stressed thus causing some membrane damage thereby, releasing pro-inflammatory mediators. The presence of a HP corona reduced the uptake of BPEI-AuNP significantly, thereby causing IL- $1 \alpha$ and IL- $1 \beta$ secretion to be dramatically reduced compared to bare AuNP (Figure 9B \& D). IL-1 $\beta$ secretion indicates that HEK had entered an activation state in response to these NP. The same effect was seen with IL-8 which is a chemokine that can recruit neutrophils to the infection site. IL-8 was highly secreted by HEK after incubation with all AuNP at $48 \mathrm{~h}$, while 40 and $80 \mathrm{~nm}$ BPEI-AuNP triggered IL-8 secretion at $24 \mathrm{~h}$ (Figure 9E). IL-8 has been seen in response to injury or irritation and in hyperproliferative disorders such as acute contact dermatitis

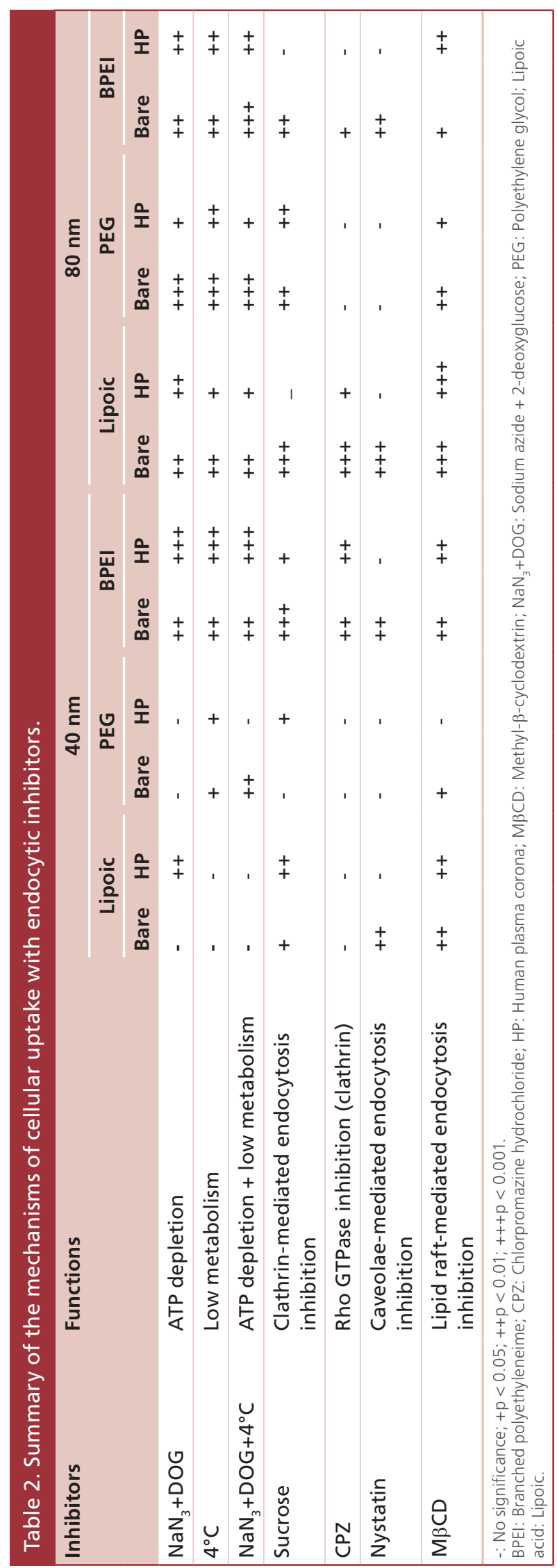




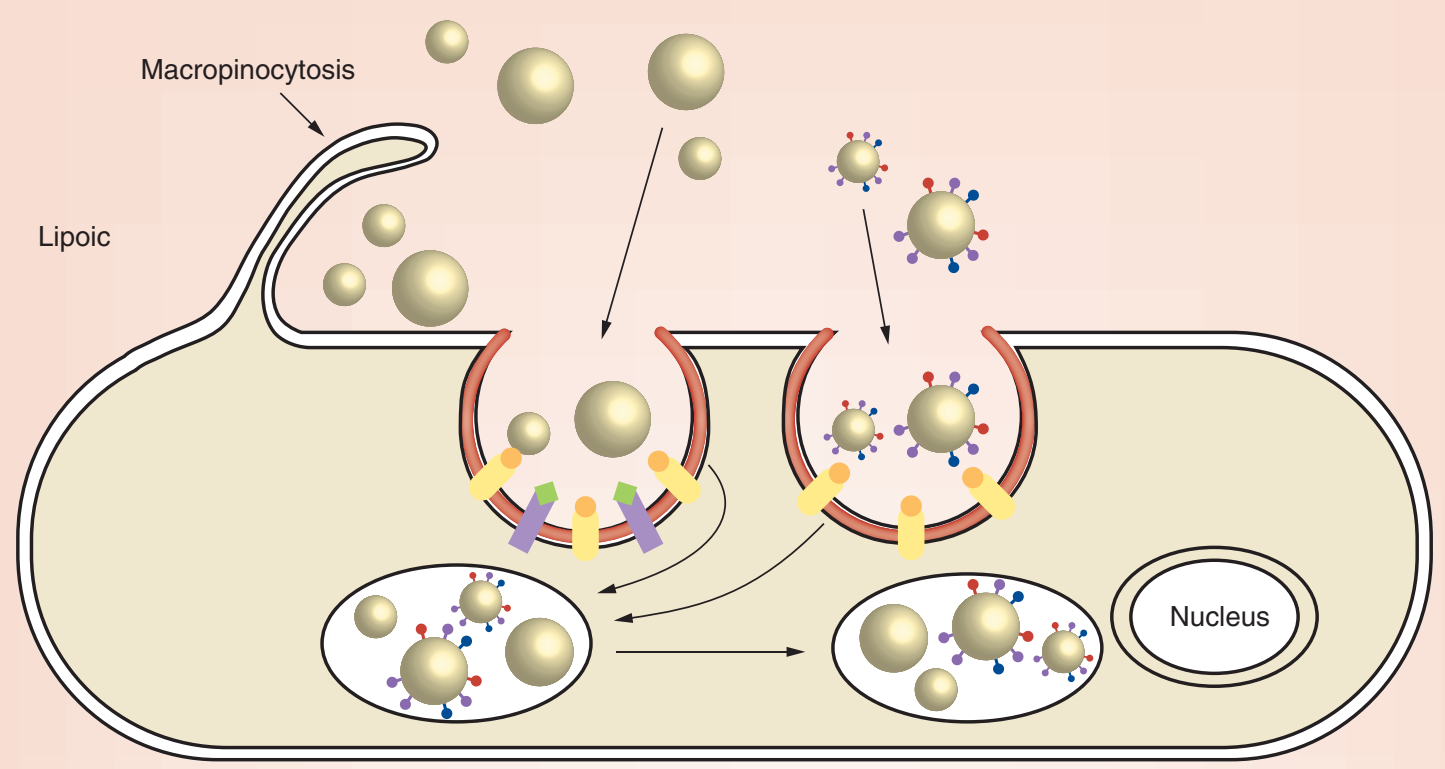

PEG

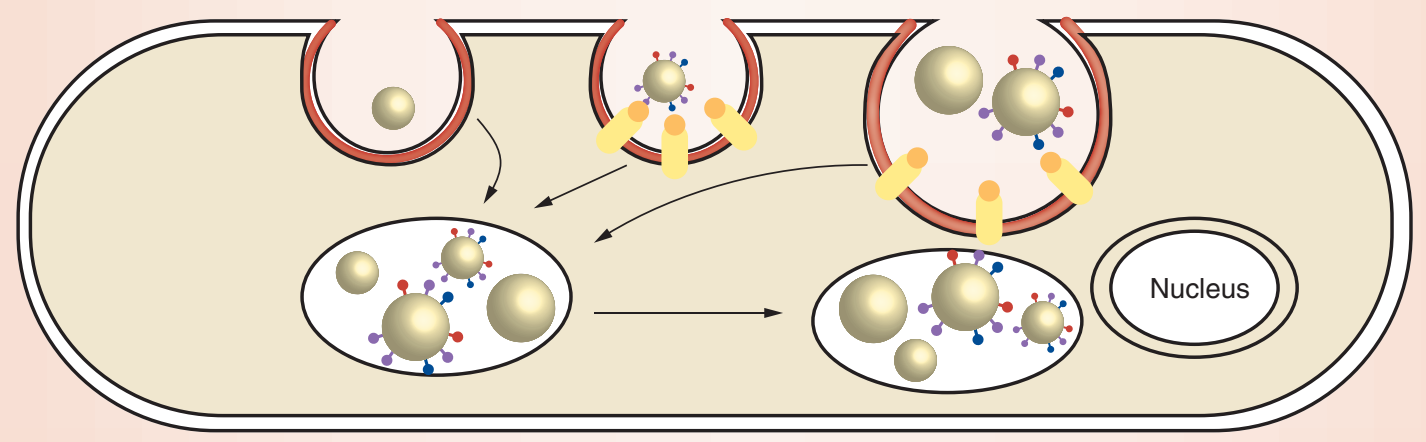

BPEI
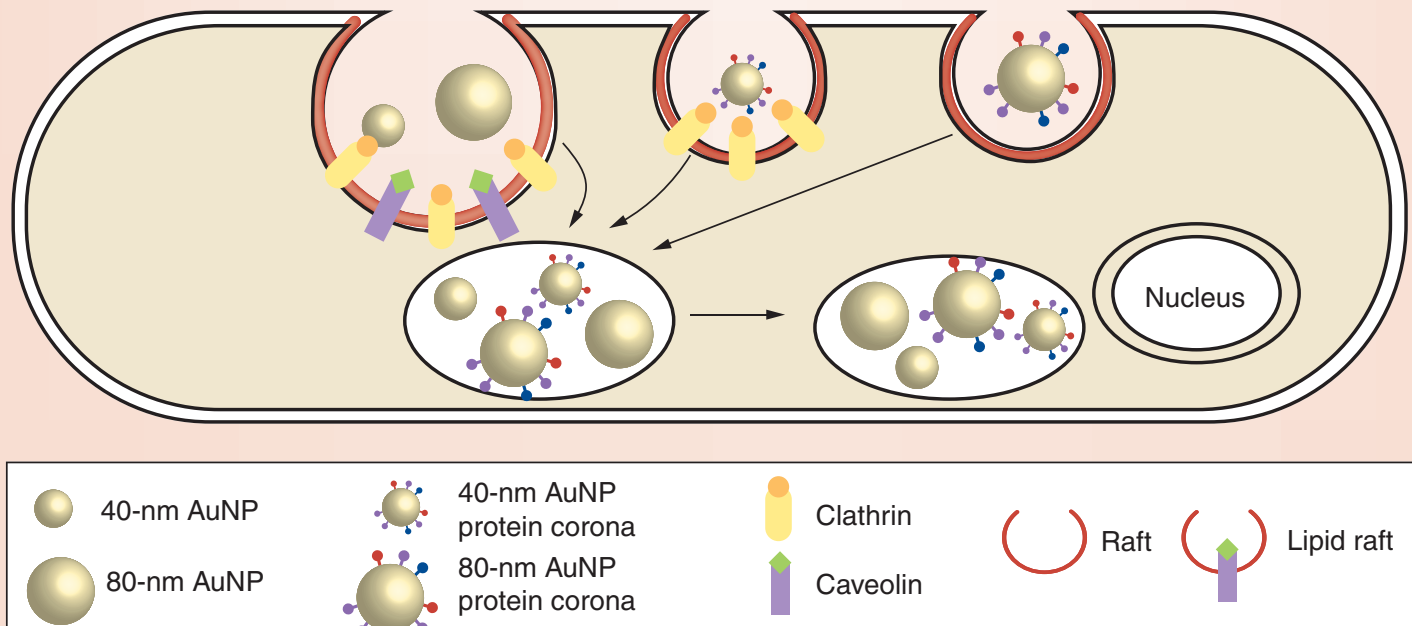

40-nm AuNP protein corona 80-nm AuNP protein corona

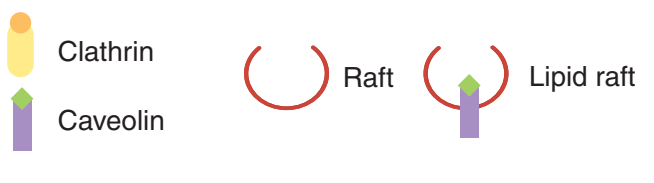

Figure 8. Schematic diagram of gold nanoparticles cellular uptake pathways. Clathrin and lipid raft-mediated endocytic pathways. Lipid raft endocytosis is subdivided as caveolin and raft/noncaveolin-mediated endocytic pathways. AuNP: Gold nanoparticles; BPEI: Branched polyethyleneimine; Lipoic: Lipoic acid; PEG: Polyethylene glycol. 


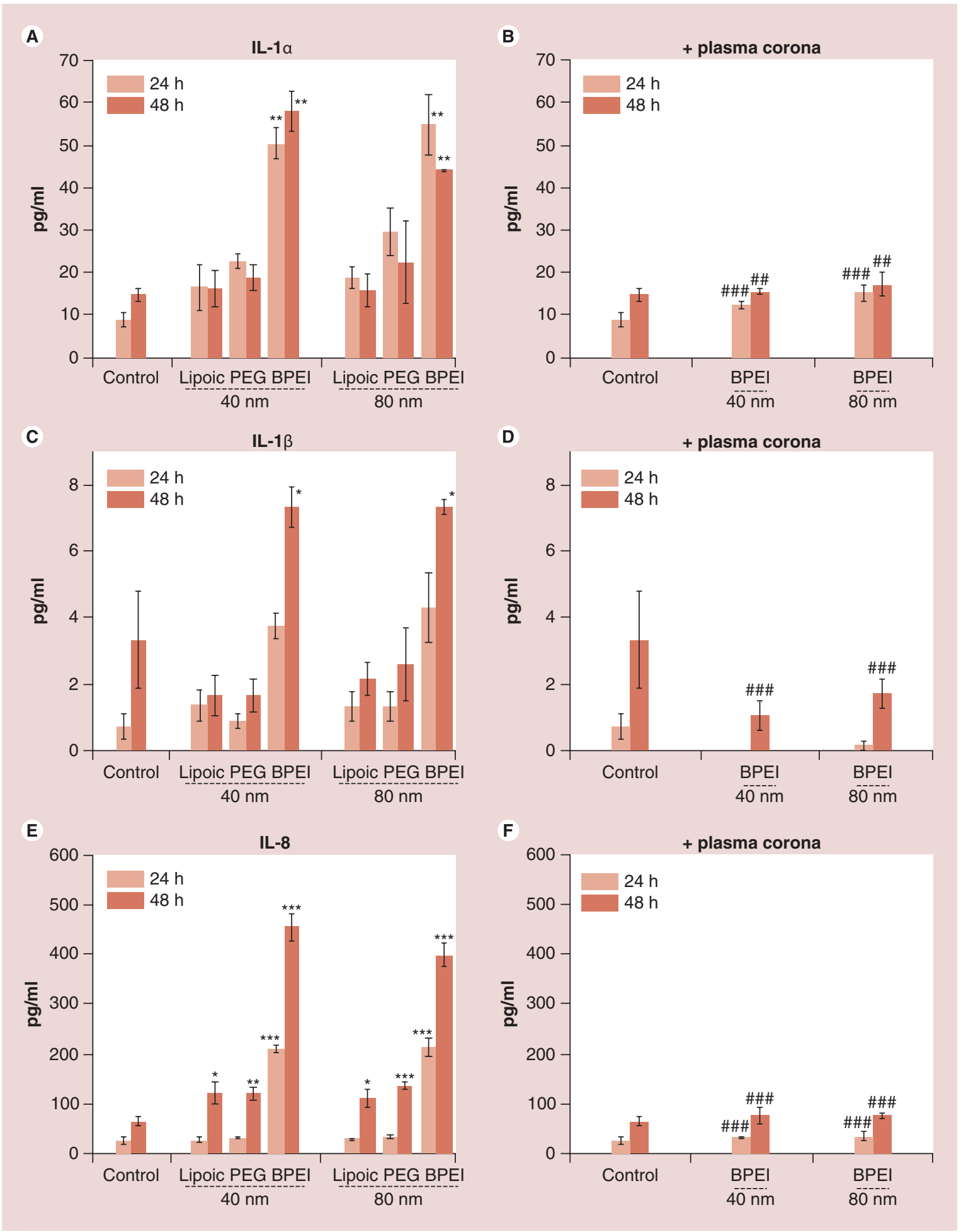

Figure 9. Proinflammatory cytokines IL-1 $\alpha$, IL-1 $\beta$ and chemokine IL-8 secretion in human epidermal keratinocytes after treatment with gold nanoparticles. Human epidermal keratinocytes were exposed to $25 \mu \mathrm{g} / \mathrm{ml}$ of 40 and $80 \mathrm{~nm}$ lipoic-, PEG- and BPEI-gold nanoparticles (AuNP) in the absence (A, C \& E) or presence (B, D \& F) of human plasma protein corona for 24 and 48 h. Data represent mean \pm SD ( $n=3$ wells/treatment).

${ }^{*} p<0.05, * * p<0.01, * * * p<0.001$ AuNP versus control.

$\# \mathrm{p}<0.01$, \#\#\# $<0.001$ of human plasma versus bare AuNP.

BPEI: Branched polyethyleneime; Lipoic: Lipoic acid; PEG: Polyethylene glycol. 
and psoriasis [52,53]. HEK release TNF- $\alpha$ and IL- $1 \beta$ that are capable of stimulating the production of IL- 8 in a time-dependent manner $[54,55,56]$. IL-8 is not found in normal skin but rather plays a significant role in dermal injuries and in inflammatory skin diseases [57]. These cytokines are produced in a wide variety of chemicals, irritants, sensitizers, allergens and jet fuels $[58,59,60]$. IL-8 expression in HEK have been reported with several types of NP including multi-walled carbon nanotubes (MWCNT) [54], single walled carbon nanotubes [61], quantum dots [62], functionalized $\mathrm{C}_{60}$ [63], silver $\mathrm{NP}$ [64], aluminum [65] and others [66]. In the presence of a HP corona, IL-8 secretion was eliminated (Figure 9F). This is similar to other studies with MWCNT treated with the ionic surfactant Pluronic F-127 which coated the MWCNT thereby, decreasing the IL-8 expression [56]. All of these results suggest that the presence of a HP protein corona with AuNP could significantly suppress the inflammatory effects making it more biocompatible for biomedical applications. Since protein coronas decreased the uptake of AuNP, this could also reduce oxidative stress within the cells but it might also decrease the surface reactivity by providing a more biocompatible surface.

\section{Conclusion}

This research shows that HP and HSA protein coronas can significantly reduce the cellular uptake of 40 and $80 \mathrm{~nm}$ lipoic, PEG and BPEI-AuNP in HEK. Also, HP protein coronas on AuNP can reduce the pro-inflammatory responses. The mechanistic cell uptake study suggests that AuNP were internalized by clathrin and lipid raft-mediated endocytosis, except for the $40 \mathrm{~nm}$ PEGAuNP which showed cell uptake by raft-/noncaveolaemediated endocytosis. HP coronas may inhibit the caveolae-mediated endocytosis in lipoic and BPEI-AuNP and alter the $40 \mathrm{~nm}$ PEG-AuNP route from raft-/noncaveolae-mediated to the clathrin-mediated pathways. However, in the presence of HP coronas, $80 \mathrm{~nm}$ PEGAuNP showed no effect. This study stresses the important interrelationships between size, surface coating and protein coronas of AuNP on the mechanisms of cellular uptake and inflammatory potential, thereby, providing a better understanding of the role of protein coronas have on cellular uptake pathways and inflammatory effects.

\section{Supplementary data}

To view the supplementary data that accompany this paper please visit the journal website at: www.futuremedicine.com/ doi/full/10.2217/nnm-2016-0303

\section{Acknowledgements}

The authors thank Dr Sasidharan for preparing the protein corona and Dr Zhang for ICP-MS technical support. The authors also thank Mr R Thakkar for TEM support and Ms M Hoover for drawing Figure 8.

\section{Financial \& competing interests disclosure}

This research was supported by the Nanotechnology Innovation Center of Kansas State University. The authors have no other relevant affiliations or financial involvement with any organization or entity with a financial interest in or financial conflict with the subject matter or materials discussed in the manuscript apart from those disclosed.

No writing assistance was utilized in the production of this manuscript.

\section{Open access}

This work is licensed under the Creative Commons Attribution-NonCommercial 4.0 Unported License. To view a copy of this license, visit http://creativecommons.org/licenses/bync-nd/4.0/

Executive summary

- The physicochemical properties of gold nanoparticles (AuNP) play an extremely important role on the formation of a protein corona, mechanisms of cell uptake, and inflammation.

- Cellular uptake for 40 and $80 \mathrm{~nm}$ lipoic acid, polyethylene glycol (PEG), and branched polyethyleneimine (BPEI)-AUNP from $15 \mathrm{~min}$ to $48 \mathrm{~h}$ in human epidermal keratinocytes (HEK) showed different effects in the absence or presence of a protein corona.

- BPEI-AUNP showed the greatest cellular uptake in HEK, whereas the PEG-AuNP had the least. Protein coronas significantly decreased AuNP cell uptake.

- The rate of cell uptake and not just the amount of uptake are important factors to profile NP cellular internalization.

- Most AuNP uptake was energy-dependent, except for $40 \mathrm{~nm}$ lipoic acid-AuNP. Almost all AuNP were internalized by clathrin and lipid raft/noncaveolae mediated endocytosis, except for $40 \mathrm{~nm}$ PEG-AuNP which was by raft/noncaveolae mediated endocytosis.

- Protein coronas inhibited caveolae-mediated endocytosis with lipoic acid and BPEI-AuNP and altered the 40 $\mathrm{nm}$ PEG-AuNP pathway from raft/noncaveolae to clathrin-mediated endocytosis.

- Protein coronas did not alter the 80nm PEG-AuNP endocytic pathway.

- Protein coronas on AUNP can significantly affect cell uptake and proinflammatory responses in HEK. 


\section{References}

Papers of special note have been highlighted as: • of interest;

•• of considerable interest

1 Wang $\mathrm{H}, \mathrm{Huff} \mathrm{TB}, \mathrm{Zweifel} \mathrm{DA}$ et al. In vitro and in vivo two-photon luminescence imaging of single gold nanorods. Proc. Natl Acad. Sci. USA 102(44), 15752-15756 (2005).

2 Ghosh P, Han G, De M, Kim CK, Rotello VM. Gold nanoparticles in delivery applications. Adv. Drug Deliv. Rev. 60(11), 1307-1315 (2008).

3 Zhang Z, Wang L, Wang J et al. Mesoporous silicacoated gold nanorods as a light-mediated multifunctional theranostic platform for cancer treatment. Adv. Mater. 24(11), 1418-1423 (2012).

4 Albanese A, Tang PS, Chan WC. The effect of nanoparticle size, shape, and surface chemistry on biological systems. Annu. Rev. Biomed. Eng. 14, 1-16 (2012).

5 Zhang S, Li J, Lykotrafitis G, Bao G, Suresh S. Sizedependent endocytosis of nanoparticles. Adv. Mater. 21(4), 419-424 (2009).

6 Jiang W, Kim BY, Rutka JT, Chan WC. Nanoparticlemediated cellular response is size-dependent. Nat. Nanotech. 3(3), 145-150 (2008).

- $\quad$ Size-dependent effects on activation of membrane receptors and subsequent protein expression.

7 Sonavane G, Tomoda K, Makino K. Biodistribution of colloidal gold nanoparticles after intravenous administration: effect of particle size. Colloids Surf. B Biointerfaces 66(2), 274-280 (2008).

8 Verma A, Stellacci F. Effect of surface properties on nanoparticle-cell interactions. Small 6(1), 12-21 (2010).

9 Chithrani BD, Ghazani AA, Chan WC. Determining the size and shape dependence of gold nanoparticle uptake into mammalian cells. Nano Lett. 6(4), 662-668 (2006).

- Size-dependent cell uptake on gold nanoparticles.

10 Cho EC, Xie J, Wurm PA, Xia Y. Understanding the role of surface charges in cellular adsorption versus internalization by selectively removing gold nanoparticles on the cell surface with a I2/KI etchant. Nano Lett. 9(3), 1080-1084 (2009).

-. Describes an etching protocol to remove the surfaceattached gold nanoparticles.

11 Ryman-Rasmussen JP, Riviere JE, Monteiro-Riviere NA. Variables influencing interactions of untargeted quantum dot nanoparticles with skin cells and identification of biochemical modulators. Nano Lett. 7(5), 1344-1348 (2007).

12 Ryman-Rasmussen JP, Riviere JE, Monteiro-Riviere NA. Penetration of intact skin by quantum dots with diverse physicochemical properties. Toxicol. Sci. 91(1), 159-165 (2006).

13 Saha K, Kim ST, Yan B et al. Surface functionality of nanoparticles determines cellular uptake mechanisms in mammalian cells. Small 9(2), 300-305 (2013).

14 Jiang Y, Huo S, Mizuhara T et al. The interplay of size and surface functionality on the cellular uptake of sub10 nm gold nanoparticles. ACS Nano 9(10), 9986-9993 (2015).
15 Monopoli MP, Walczyk D, Campbell A et al. Physicalchemical aspects of protein corona: relevance to in vitro and in vivo biological impacts of nanoparticles. J. Am. Chem. Soc. 138(8), 2525-2534 (2011).

16 Lundqvist M, Stigler J, Elia G, Lynch I, Cedervall T, Dawson KA. Nanoparticle size and surface properties determine the protein corona with possible implications for biological impacts. Proc. Natl Acad. Sci. USA 105(38), 14265-14270 (2008).

- $\quad$ Size and surface properties play an important role in determining the nanoparticle protein coronas.

17 Lynch I, Salvati A, Dawson KA. Protein-nanoparticle interactions: what does the cell see? Nat. Nanotech. 4, 546-547 (2009).

18 Monteiro-Riviere NA, Samberg ME, Oldenburg SJ, Riviere JE. Protein binding modulates the cellular uptake of silver nanoparticles into human cells: implications for in vitro to in vivo extrapolations? Toxicol. Lett. 220(3), 286-293 (2013).

19 Walkey CD, Olsen JB, Guo H, Emili A, Chan WC. Nanoparticle size and surface chemistry determine serum protein adsorption and macrophage uptake. J. Am. Chem. Soc. 134(4), 2139-2147 (2012).

20 Lesniak A, Fenaroli F, Monopoli MP, Åberg C, Dawson KA, Salvati A. Effects of the presence or absence of a protein corona on silica nanoparticle uptake and impact on cells. ACS Nano 6(7), 5845-5857 (2012).

21 Huang X, Teng X, Chen D, Tang F, He J. The effect of the shape of mesoporous silica nanoparticles on cellular uptake and cell function. Biomaterials 31(3), 438-448 (2010).

22 Boraschi D, Costantino L, Italiani P. Interaction of nanoparticles with immunocompetent cells: nanosafety considerations. Nanomedicine 7(1), 121-131 (2012).

23 Conner SD, Schmid SL. Regulated portals of entry into the cell. Nature 422(6927), 37-44 (2003).

- A review on endocytic mechanisms.

24 Le Roy C, Wrana JL. Clathrin- and non-clathrin-mediated endocytic regulation of cell signalling. Nat. Rev. Mol. Cell Biol. 6(2), 112-126 (2005).

25 Li Y, Boraschi D. Endotoxin contamination: a key element in the interpretation of nanosafety studies. Nanomedicine 11(3), 269-287 (2016).

- The importance of using endotoxin-free nanoparticles.

26 Li Y, Italiani P, Casals E, Tran N, Puntes VF, Boraschi D. Optimising the use of commercial LAL assays for the analysis of endotoxin contamination in metal colloids and metal oxide nanoparticles. Nanotoxicology 9(4), 462-473 (2015).

27 Monteiro-Riviere NA, Inman AO, Zhang LW. Limitations and relative utility of screening assays to assess engineered nanoparticle toxicity in a human cell line. Toxicol. Appl. Pharmacol. 234(2), 222-235 (2009).

28 Wang L, Liu Y, Li W et al. Selective targeting of gold nanorods at the mitochondria of cancer cells: implications for cancer therapy. Nano Lett. 11(2), 772-780 (2010).

29 Zhang LW, Monteiro-Riviere NA. Mechanisms of quantum dot nanoparticle cellular uptake. Toxicol. Sci. 110(1), 138-155 (2009). 
30 Allabashi R, Stach W, De La Escosura-Muñiz A, Liste-Calleja L, Merkoçi A. ICP-MS: a powerful technique for quantitative determination of gold nanoparticles without previous dissolving. J. Nanopart. Res. 11(8), 2003-2011 (2009).

- The calculation method of the mass of intracellular gold that converted to the gold nanoparticle numbers.

31 Sasidharan A, Riviere JE, Monteiro-Riviere NA. Gold and silver nanoparticle interactions with human proteins: impact and implications in biocorona formation. J. Mater. Chem. B 3(10), 2075-2082 (2015).

32 Murali K, Kenesei K, Li Y, Demeter K, Környei Z, Madarász E. Uptake and bio-reactivity of polystyrene nanoparticles is affected by surface modifications, ageing and LPS adsorption: in vitro studies on neural tissue cells. Nanoscale 7(9), 4199-4210 (2015).

33 Xie J, Xu C, Kohler N, Hou Y, Sun S. Controlled PEGylation of monodisperse $\mathrm{Fe} 3 \mathrm{O} 4$ nanoparticles for reduced nonspecific uptake by macrophage cells. Adv. Mater. 19(20), 3163-3166 (2007).

34 Cheng X, Tian X, Wu A et al. Protein corona influences cellular uptake of gold nanoparticles by phagocytic and nonphagocytic cells in a size-dependent manner. ACS Appl. Mater. Interfaces 7(37), 20568-20575 (2015).

35 Walkey CD, Chan WC. Understanding and controlling the interaction of nanomaterials with proteins in a physiological environment. Chem. Soc. Rev. 41(7), 2780-2799 (2012).

36 Chandran P, Monteiro-Riviere NA. Role of physicochemical properties of gold nanoparticles on biocorona formation and cellular uptake profiles in endothelial cells. Presented at: The 8th International Nanotoxicology Congress, MA, USA, 1-4 June 2016.

37 Mcmahon HT, Boucrot E. Molecular mechanism and physiological functions of clathrin-mediated endocytosis. Nat. Rev. Mol. Cell Biol. 12(8), 517-533 (2011).

38 Heuser JE, Anderson R. Hypertonic media inhibit receptormediated endocytosis by blocking clathrin-coated pit formation. J. Cell Biol. 108(2), 389-400 (1989).

39 Zhang LW, Yang J, Barron AR, Monteiro-Riviere NA. Endocytic mechanisms and toxicity of a functionalized fullerene in human cells. Toxicol. Lett. 191(2), 149-157 (2009).

40 Chen C-L, Hou W-H, Liu I-H, Hsiao G, Huang SS, San Huang J. Inhibitors of clathrin-dependent endocytosis enhance TGF $\beta$ signaling and responses. J. Cell Sci. 122(11), 1863-1871 (2009).

41 Simons K, Ikonen E. Functional rafts in cell membranes. Nature 387(6633), 569-572 (1997).

- The concept and general properties of lipid rafts-mediated endocytosis.

42 Lajoie P, Nabi IR. Lipid rafts, caveolae, and their endocytosis. Int. Rev. Cell Mol. Biol. 282, 135-163 (2010).

43 Nabi IR, Le PU. Caveolae/raft-dependent endocytosis. J. Cell Biol. 161(4), 673-677 (2003).

44 Rodal SK, Skretting G, Garred ø, Vilhardt F, Van Deurs B, Sandvig K. Extraction of cholesterol with methyl- $\beta$ cyclodextrin perturbs formation of clathrin-coated endocytic vesicles. Mol. Biol. Cell 10(4), 961-974 (1999).
45 Ivanov AI. Exocytosis and Endocytosis. Springer, NY, USA (2008).

46 Li Y, Liu Y, Fu Y et al. The triggering of apoptosis in macrophages by pristine graphene through the MAPK and TGF-beta signaling pathways. Biomaterials 33, 402-411 (2012).

47 Rider P, Carmi Y, Voronov E, Apte RN. Interleukin-1 $\alpha$. Semin. Immunol. 25(6), 430-438 (2013).

48 Werman A, Werman-Venkert R, White R et al. The precursor form of IL-1 $\alpha$ is an intracrine proinflammatory activator of transcription. Proc. Natl Acad. Sci. USA 101(8), 2434-2439 (2004).

49 Rider P, Carmi Y, Guttman O et al. IL-1 $\alpha$ and IL-1 $\beta$ recruit different myeloid cells and promote different stages of sterile inflammation. J. Immunol. 187(9), 4835-4843 (2011).

50 Eigenbrod T, Park J-H, Harder J, Iwakura Y, Núñez G. Cutting edge: critical role for mesothelial cells in necrosisinduced inflammation through the recognition of IL-1 $\alpha$ released from dying cells. J. Immunol. 181(12), 8194-8198 (2008).

51 Cohen I, Rider P, Carmi Y et al. Differential release of chromatin-bound IL-1 $\alpha$ discriminates between necrotic and apoptotic cell death by the ability to induce sterile inflammation. Proc. Natl Acad. Sci. USA 107(6), 2574-2579 (2010).

52 Nickoloff BJ. Pathophysiology of cutaneous inflammation. Arch. Dermatol. Res. 284(1), S10-S11 (1992).

53 Nickoloff B, Karabin G, Barker J et al. Cellular localization of interleukin- 8 and its inducer, tumor necrosis factor-alpha in psoriasis. Am. J. Pathol. 138(1), 129 (1991).

54 Monteiro-Riviere NA, Nemanich RJ, Inman AO, Wang YY, Riviere JE. Multi-walled carbon nanotube interactions with human epidermal keratinocytes. Toxicol. Lett. 155(3), 377-384 (2005).

55 Allen DG, Riviere JE, Monteiro-Riviere NA. Analysis of interleukin-8 release from normal human epidermal keratinocytes exposed to aliphatic hydrocarbons: delivery of hydrocarbons to cell cultures via complexation with $\alpha$-cyclodextrin. Toxicol. In Vitro 15(6), 663-669 (2001).

56 Monteiro-Riviere NA, Inman AO, Wang YY, Nemanich RJ. Surfactant effects on carbon nanotube interactions with human keratinocytes. Nanomed. Nanotech. Biol. Med. 1(4), 293-299 (2005).

57 Chabot-Fletcher M, Breton J, Lee J, Young P, Griswold DE. Interleukin- 8 production is regulated by protein kinase $\mathrm{C}$ in human keratinocytes. J. Invest. Dermatol. 103(4), 509-515 (1994).

58 Monteiro-Riviere NA, Baynes RE, Riviere JE. Pyridostigmine bromide modulates topical irritant-induced cytokine release from human epidermal keratinocytes and isolated perfused porcine skin. Toxicology 183(1), 15-28 (2003).

59 Mohamadzadeh M, Miiller M, Hultsch T, Enk A, Saloga J, Knop J. Enhanced expression of IL-8 in normal human keratinocytes and human keratinocyte cell line $\mathrm{HaCaT}$ in vitro after stimulation with contact sensitizers, tolerogens and irritants. Exp. Dermatol. 3(6), 298-303 (1994). 
60 Allen DG, Riviere JE, Monteiro-Riviere NA. Identification of early biomarkers of inflammation produced by keratinocytes exposed to jet fuels jet A, JP-8, and JP-8 (100). J. Biochem. Mol. Toxicol. 14(5), 231-237 (2000).

61 Zhang LW, Zeng L, Barron AR, Monteiro-Riviere NA. Biological interactions of functionalized single-wall carbon nanotubes in human epidermal keratinocytes. Int. J. Toxicol. 26(2), 103-113 (2007).

62 Ryman-Rasmussen JP, Riviere JE, Monteiro-Riviere NA. Surface coatings determine cytotoxicity and irritation potential of quantum dot nanoparticles in epidermal keratinocytes. J. Invest. Dermatol. 127(1), 143-153 (2007).

63 Rouse JG, Yang J, Barron AR, Monteiro-Riviere NA. Fullerene-based amino acid nanoparticle interactions with human epidermal keratinocytes. Toxicol. In Vitro 20(8), 1313-1320 (2006).
64 Samberg ME, Oldenburg SJ, Monteiro-Riviere NA. Evaluation of silver nanoparticle toxicity in skin in vivo and keratinocytes in vitro. Environ. Health Perspect. 118(3), 407-413 (2010).

65 Monteiro-Riviere NA, Oldenburg SJ, Inman AO. Interactions of aluminum nanoparticles with human epidermal keratinocytes. J. Appl. Toxicol. 30 (3), 276-285 (2010).

66 Monteiro-Riviere NA, Tran CL. Nanotoxicology: Characterization, Dosing and Health Effects. Informa Healthcare Inc., NY, USA (2007).

- General overview of nanoparticle cell interactions in different organ systems. 